\title{
Sobre la soberanía y lo político
}

\author{
FERNANDO ATRIA LEMAITRE* \\ UNIVERSIDAD DE CHILE \\ UNIVERSIDAD ADOLFO IBÁÑEZ
}

Resumen: El autor analiza y critica las teorías jurídicas y políticas existentes que buscan explicar el significado del 11 de septiembre de 1973. Partiendo de la obra de Renato Cristi, la cual discute en sus conclusiones. Finalmente, expone sus propias propuestas, dándole relevancia no sólo para el tema particular del proceso constitucional chileno, sino para conceptos centrales de la filosofía política y jurídica.

Abstract: Abstract: The author analyzes and criticizes the existing legal and political theories that look for the explain of the meaning of the 11 of September of 1973 September 11th 1973. Starting off from the work of Renato Cristi, which is discussed in his conclusions. Finally, he exposes his own proposals, giving they relevance not only for the particular subject of the Chilean constitutional process, but also for central concepts of the political and legal philosophy.

Palabras clave: proceso constituyente chileno, Constitución de 1980, poder constituyente, tiranía, dictadura, violencia constitutiva, política, soberanía.

Key words: constituent power, dictatorship, constitutive violence, politic.

¿Qué ocurrió en Chile el 11 de Septiembre de 1973? La respuesta a esta pregunta es en algún sentido evidente para todos los chilenos, aunque notoriamente opaca en otros. En este artículo quiero enfrentarla desde el punto de vista de la teoría jurídica y política. Parte de lo que deseo mostrar aquí es que las teorias disponibles para explicar esos hechos son seriamente deficitarias. Por diversas razones ellas se muestran incapaces de entender lo que en términos constitucionales es importante en el tiempo que comenzó ese día. La clave para develar este misterio estará en desentrañar la dinámica existente entre lo universal y lo particular o, para decirlo en otros términos, enire normalidad y excepción.

Pero entender el proceso chileno es importante no sólo porque nos permite a los chilenos entender nuestra histórica política reciente y nuestra situación constitucional actual. Adicionalmente, la discusión del proceso chileno es la discusión de una serie de conceptos centrales de la filosofía política y jurídica. Aquí lo que nos ocupará setá el problema del poder constituyente y su identificación en los eventos que siguieron al bombardeo de La Moneda el 11 de septiembre.

Para ello, quieto preguntarme sobre lo que de modo cándido por ahora podemos llamar "el proceso constitucional chileno" desde 1973. Quiero hacerlo en diálogo con el profesor Renato Cristi,

* Licenciado en Ciencias Jurídicas y Sociales, Universidad de Chile. Abogado. Ph.D., Universidad de Edimburgo. Profesor de las facultades de Derecho de la Universidad de Chile y de la U. Adolfo Ibáñez. Correo: fernando.atria@uai.cl 
quien hasta donde yo sé es el único que ha reconocido, en su El Pensamiento Político de Jaime Guzmán, la importancia de hacer una interpretación teóricamente sofisticada de ese proceso. El hecho de que, como se verá, la posición adoptada en este artículo esté en directa oposición a la defendida por Cristi en su estudio de la función y significación de Jaime Guzmán en el período post-1973 no quiere decir que ese estudio no sea, hoy por hoy, el punto de partida obligado para una reflexión como la que sigue.

Cristi sigue la figura de Jaime Guzmán y el rol que a éste le cupo en la configuración del orden constitucional que se inauguta en 1980, y en el camino ofrece una explicación del proceso político chileno posterior a 1973. La clave interpretativa Cristi la encuentra en el 'Kronjurist' del nacionalsocialismo alemán, Carl Schmitt. Cristi, en efecto, debe ser uno de los más calificados para realizar una interpretación como ésta, en tanto autor de un cuidadoso estudio sobre las teorías jurídicas y políticas de Carl Schmitt' ${ }^{1}$. Por esa interpretación es por donde debemos comenzar.

\section{3 y el proceso constituyente posterior}

"Exponer el pensamiento de [Carl] Schmitt ", sostiene Renato Cristi, "resulta indispensable para entender cabalmente el devenir constitucional chileno a partir de $1973^{32}$. No está claro qué es lo que quiere decir Cristi con esta afirmación, de la cual caben dos interpretaciones. En efecto, ella podría significar que entre los ideólogos de la dictadura militar (Jaime Guzmán en particular) la idea schmittiana de constitución y poder constituyente fue utilizada como guía, por lo que entenderemos mejor lo que estas personas (creían que) estaban haciendo si lo miramos con lentes schmittianos ${ }^{3}$. Pero la idea de Cristi resiste una interpretación distinta y más interesante: Cristi podría estar sosteniendo que la Verfassungslehre de Carl Schmitt provee, en sus propios términos, del instrumental teórico más adecuado para comprender el devenit constitucional chileno desde 1973. La diferencia entre estas dos posiciones es evidente desde que consideramos que la verdad de la primera depende de (algunos de) los estados mentales de los ideólogos de la dictadura militar: ¿eran ellos guiados por una interpretación schmittiana de las cosas? Esta cuestión resulta puramente anecdótica, y sin valor intrínseco alguno, si lo que nos interesa es la segunda interpretación. Veremos más adelante que la ambigüedad entre estas dos tesis es importante para el argumento de Cristi.

En todo caso, la interpretación schmittiana de ese devenir constitucional que Cristi ofrece corre más o menos como sigue: Aún cuando por tazones comunicacionales o estratégicas la junta militar no estaba inmediatamente dispuesta a admitirlo, la Constitución de 1925 fue destruida el 11 de septiembre de 1973. "Destruida" es aquí un término técnico que debe ser distinguido de "suprimida". Una constitución es destruida cuando el poder constituyente sobre el que ella descansa es negado ${ }^{4}$, y es

1 Cristi, Carl Scbmitt.

2 Ctisti, El pensamiento político de Jaime Gurmán, 77-78.

3 A ratos Ctisti parece insinuat que ésta es su tesis: " $\mathrm{La}$ herramienta principal empleada por Guzmán para iniciar la creación de una nueva institucionalidad es la noción de poder constituyente tal como aparece en la obra de Carl Schmitt y su discípulo español Luis Sánchez Agesta" (ibid, 16, cursivas agregadas).

4 Schmitt, Teoria de la Constitución, 110. Schmitt ofrece los siguientes ejemplos: "1789 y 1793 en Francia (supresión de la monarquía absoluta del rey), 1917-1918 en Rusia (supresión de la monarquía zarista)" (ibid. p. 111). Schmitt caracteriza la destrucción de la constitución de dos maneras: desde el punto de vista de la constitución que es destruida, como la supresión del poder constituyente, y desde el punto de vista de la constitución nueva, como la afirmación de un nuevo poder constituyente. Ambas ideas se confunden en la expresión de Schmitt, de acuerdo a la cual la destrucción de la constitución es el "cambio del poder constituyente". Peto es evidente que en términos estrictos la supresión de un poder constituyente no necesariamente implica la afirmación de un poder constituvente distinto: el poder constituyente puede ser destruido sin que un nuevo poder constituyente pueda afirmarse, caso en el cual la supresión del poder constituyente iniciatá un periodo de anarquía o guerra civil. En lo que sigue, hablaré de "destrucción de la constitución" sólo para referirme a la suptesión del poder constituyente que la animaba, sin 
suprimida cuando hay quebrantamiento parcial o completo de la constitución, pero sin variación del poder constituyentes. Cristi afirma que "a partir del 11 de septiembre de 1973, la constitución de 1925 dejaba de existir". Para justificar esta afirmación, a Cristi le resulta crucial el contenido del decreto ley 1 , en particular su artículo 3 , de acuerdo al cual la junta de gobierno "respetará la Constitución y las leyes, en la medida en que la actual situación del país lo permitan para el mejor cumplimiento de los postulados que ella se propone". Esto muestra, para Cristi, que se trata de un caso de destrucción de la constitución, porque el poder constituyente de la constitución de 1925 era el pueblo, y por eso "sólo [...] el pueblo en su totalidad podía proclamarse superior a ella"7. Al declararse superior a la Constitución de 1925 (en tanto la respetaría sólo en la medida de lo posible), la junta de gobierno se estaba arrogando el poder constituyente, y con eso negando el del pueblo.

Para explicar la supervivencia de algunas de las reglas constitucionales que incluía la constitución de 1925 a pesar de que ésta había sido destruida, es necesario hacer referencia a la distinción (sobre la que habremos de volver) que Schmitt introduce en su Teoría de la Constitución entre constitución y leyes constitucionales. Schmitt creía esta distinción era necesaria para poder dar sentido a la idea misma de constitución: "para la teoría constitucional la distinción entre constitución y ley constitucional es el comienzo de toda discusión ulterior" forma y modo de la unidad política". Las leyes constitucionales son, por su parte, teglas que figuran en el texto constitucional pero que no contienen esa decisión constitutiva: son reglas que "presuponen una constitución"?.

Armados de esta distinción, podemos seguir a Cristi: "la sobrevivencia de algunas leyes constitucionales contenidas en la llamada "constitución de 1925" (las que no fueren contrarias a lo exigido por "la situación actual del pais") no fue, en modo alguno, la supervivencia de la constitución de 1925, sino lo "que en propiedad debería llamarse 'constitución de 1973"'10. En efecto, esas reglas antiguas ahora formarían parte de un nuevo cuerpo constitucional que estatía animado por un nuevo poder constituyente originario, por una nueva decisión soberana sobte la forma y modo de existencia de la comunidad política chilena. Esa nueva decisión habría sido la de la junta militat el 11 de septiembre de 1973.

Cristi no se refiere nuevamente a lo que él aquí denomina la "constitución de 1973". De hecho, la idea de que en 1973 la constitución de 1925 fue reemplazada por otra es una idea difícil de aceptar, particularmente en el contexto de una explicación como la de Cristi. En efecto, él sostiene reiteradamente que la dictadura militar era una dictadura soberana, término también técnico que debe ser distinguido de una dictadura comisaria. Lo que caracteriza a la dictadura soberana es que mientras el dictador comisarial es el comisario de acción incondicionado de un poder constituido, la dictadura soberana es la comisión de acción incondicionada de un poder constituyente ${ }^{11}$.

La diferencia entre una dictadura comisaria y una soberana es de extraordinaria importancia. Dictadura, políticamente, es "todo ejercicio del poder estatal que se realice de una manera inmediata,

\footnotetext{
implicat nada respecto de su reemplazo por un nuevo poder constituyente. La importancia de este punto se hará progtesivamente evidente a medida que el argumento progrese.

5 ibid, 109s. Ejemplos: "las revoluciones francesas y golpes de estado de 1848, 1851, 1852 y 1870". En ellos, a pesar del "cambio constitucional con quebtantamiento o suptesión de las constituciones existentes hasta ese momento", se mantuvo el reconocimiento "del poder constituyente del pueblo francés" (Schmitt, Teoría de la Constitución, 110).

6 Cristi, Jaime Gựmán, 82.

7 ibid, 83.

8 Schmitt, Teoria de la Constitución, 45.

9 ibid, 46.

10 Cristi, Jaime Guzman, 82.

11 Schmitt, La Dictadura, 193.
} 
es decir, no mediatizado a través de instancias intermedias independientes"12. La dictadura es (def.=) suspensión del detecho. Esto permite distinguir a la dictadura (comisaria o soberana) de la tiranía, que lo destruye.

Siendo ambos tipos de dictaduras ejercicios no mediados del poder estatal, lo característico de la dictadura comisaria es que "suspende la constitución in concreto, para proteger la misma constitución en su existencia concreta"13. El paradigma de dictadura comisaria eta la dictaduta tomana ${ }^{14}$. El dictador romano eta un magistrado nombrado por un cónsul cuando el Senado había decidido que la dictadura era necesaria. Durante la dictadura, que duraba seis meses, el derecho y los procedimientos eran suspendidos. Al terminar la dictadura el dictador debía rendir cuenta de lo realizado durante ella.

En el caso de la dictadura romana, la dictadura era necesaria porque era la adhesión al derecho en las circunstancias concretas que Roma atravesaba lo que constituía un peligro para la mantención del orden político. La dictadura era aquí un medio para proteger ese orden, lo que exigía suspender el derecho. En esto la dictadura tomana (comisaria) se diferencia de la dictadura soberana, que ve ahora en la ordenación total existente la situación que se quiere eliminar mediante su acción. No suspende una constitución existente valiéndose de un derecho fundamentado en ella, y por tanto, constitucional, sino que aspira a crear una situación que haga posible una constitución, a la que considera como la constitución verdadera. En consecuencia, no apela a una constitución existente, sino a una constitución que va a implantar ${ }^{15}$.

Lo anterior muestra en primer lugar que Cristi se apresura al declarar a la Junta de Gobierno a la cabeza de una dictadura soberana por el hecho de que haya declarado, en el decreto ley 1 , que respetaría la constitución en la medida en que fuera posible. Cristi parece creer que porque la Junta de Gobierno declaró suspendido el derecho ella debe ser entendida como una dictadura soberana. Pero por supuesto, eso elimina la distinción entre dictadura soberana y comisaria, porque lo que es común a ambas es precisamente la suspensión del derecho, la inmediación en el ejercicio del poder. Por otra parte, al calificar lo que ocurrió el 11 de septiembre como "destrucción" de la constitución, Cristi ya está caracterizando al régimen de la junta de gobierno como dictadura soberana (porque una dictadura comisaria no destruye sino defiende la constitución). Pero esta caracterización es, adicionalmente, incompatible con su idea de que existe una constitución de 1973, porque entonces la dictadura no podría haber sido soberana sino un comisario de acción condicionado de la constitución de 1973 (porque la dictadura comisaria destruye la constitución apelando a una futura).

Aquí llegamos a uno de los puntos cruciales del argumento a ser desarrollado, que nos muestra adicionalmente la importancia de distinguir las dos interpretaciones de la tesis de Cristi mencionadas más arriba. No hay ninguna razón por la cual el sentido de la interrupción del detecho realizada el 11 de septiembre deba haber sido transparente para los agentes que la protagonizaron (más adelante explicaré el significado del término "interrupción" en este contexto). Ello puede sonar paradójico, tan paradójico como suena la idea de una decisión tomada inconscientemente. Pero hay buenas razones para creer que en sus primeros momentos la junta militar entendió su intervención en el sentido de iniciar una dictadura comisaria, aun cuando esto no es en absoluto decisivo para determinar si efectivamente era (o terminó siendo) una dictadura comisaria. El punto puede y debe ser radicalizado: no hay tazón para creer que el mismo 11 sólo debía estar en duda el carácter comisario o soberano de la dictadura; en realidad no era posible decir siquiera que era una dictadura, porque para eso debemos afirmar que era suspensión del derecho, no disolución del poder y transformación de éste en pura fuerza (tiranía). De hecho, nuestro lenguaje refleja esta incertidumbre con toda claridad. Los términos

12 ibid, 179

13 ibid, 181.

14 Sobre la que véase Jolowicz, Historical Introduttion, 53-55, y Mommsen, Compendio, 223-225.

15 Schmitt, La Dictadura, 182s. 
que utilizamos para referirnos al momento fundacional hacen siempre referencia a un pasado futuro, es decir, a un futuro en el que recordaremos el presente como pasado. Un momento no puede ser constituyente, fundacional o excepcional si no es seguido por algo que es constituido, fundado o normal. Por lo tanto, la asignación de significado a un hecho como el golpe de estado de 1973 no puede ser nunca coetánea con los hechos brutos (o si lo es, la asignación coetánea de significado no tiene por eso ninguna prioridad): es parte, como veremos, de una interpretación política posterior. Esto tiene consecuencias devastadoras para el argumento de Cristi, en la medida en que elimina la importancia especial de los documentos donde constan las intenciones o deseos de los militares golpistas. Si la asignación de significado a un hecho como el golpe de estado es siempre posterior, entonces la comprensión de esos hechos que los agentes del golpe tuvieron (expresada en bandos, decretos leyes, etc) es simplemente la percepción de un agente más, y no tenemos razón alguna (al menos en principio) para reconocerles un peso especial. Esto no es sino una consecuencia de que, como lo notó Hannah Arendt, la acción política es contingente e impredecible: contingente en tanto expresa la capacidad humana de un nuevo comienzo, es decir, de hacer algo que no se encontraba ya larvado en las condiciones previas a la acción; imprevisible en tanto el significado de la acción política no es el significado privado que le asignan los actores, sino el que asume en público, donde el actor es sólo uno en una pluralidad ${ }^{16}$

De hecho, con sólo decir que el golpe "suspendió" el derecho ya estamos adelantando conclusiones, porque estamos excluyendo la posibilidad de que el derecho haya sido destruido. Por eso por ahora sólo podemos decir que el 11 de septiembre el derecho fue interrumpido (en el sentido en que "interrumpir" es agnóstico entre "destruir" y "suspender", por cuanto no implica necesariamente la idea de que la interrupción ha de cesar y el proceso continuar: no hay contradicción en la idea de una interrupción definitiva). Lo que interrumpe el derecho es la violencia, la fuerza bruta: los aviones de la fuerza aérea bombardeando el palacio de La Moneda constituyen un símbolo preciso que nos permitiría, si fuera importante, asignar incluso una hora al momento de la interrupción del derecho.

Más allá de constatar el hecho de la interrupción del derecho por los aviones que bombardearon La Moneda, los hechos del 11 de septiembre no nos pueden decir mucho más. Pero para saber más no nos sirve buscar hechos en el pasado, debemos mirar hacia el futuro para desde ahí poder volver sobre ese pasado. En efecto, la diferencia entre la suspensión del derecho y su destrucción, entre dictadura y tiranía, es visible sólo desde el futuro, como una interpretación que desde la normalidad futura podemos hacer de los hechos pasados. Sólo en la medida en que entendemos que la normalidad que se restableció (días, meses o lustros) después del golpe se funda en los hechos de ese día podemos hablar de que el 11 de septiembre se declaró la excepción: la idea de excepción es concebible sólo por referencia a la idea de normalidad.

Ahora bien, el punto de fricción entre normalidad y excepción, entre universal y particular, es la noción de poder constituyente. Por eso hemos de atender ahora a uno de los problemas centrales del libro de Cristi: el de la identificación del poder constituyente y su operación después en 1973, 1980 y 1989.

\section{La identificación del poder constituyente (i)}

En la sesión 14 de la llamada "comisión constituyente", Jaime Guzmán afirmó que la junta militar había asumido el poder constituyente derivado ${ }^{17}$. La demostración de esto radicaba en que ella

16 Arendt, Human Condition, \$\$33-34.

17 En lo sucesivo hablaré de "poder constituyente" y "poder constituido". A grandes rasgos ella concuerda con la dicotomía entre poder constituyente originario y poder constituyente derivado (Guzmán habla de "derivativo"), pero evita una setia fuente de confusión: la implicación de que ambos son dos especies de un mismo género. La dicotomía constituyente/constituido no 
estaba dispuesta, al decir de Guzmán en ese entonces, a abdicar del ejercicio del poder constituyente derivativo y restitu[ir] al poder constituyente originario la decisión del nuevo texto constitucional que vaya a regir el país ${ }^{18}$.

Para Cristi esta afirmación es un "error jurídico [que] oculta una evidente maniobra política"19, i.e. un esfuerzo por proteger la imagen internacional de la dictadura al presentarla como una dictadura comisaria, que había asumido la defensa de la constitución de 1925.

Contra Guzmán, Cristi afirma que la junta se había arrogado no el poder constituido, sino el poder constituyente. En efecto, él nos dice que el poder constituyente de la junta "necesariamente deriva de un poder constituyente originatio que no es ya el que sostenía a la constitución del 25"20, y era por eso una dictadura soberana (aunque no entiendo lo que puede querer decir "necesariamente" aquî). El problema es que las razones que llevan a Cristi a concluir como lo hace son inaceptablemente formalistas. Él considera decisivo que la figura del golpe de Estado no estaba contemplada institucionalmente en la constitución de 1925, y que la junta militar no tenía, bajo esa constitución, las competencias que luego se arrogó. Pero esto elimina la distinción entre dictadura comisaria y dictadura soberana: si el golpe de estado se hubiera limitado a derrocar al gobieno de la Unidad Popular, para luego (como muchos creyeron ${ }^{21}$ ) restablecer la institucionalidad y llamar a elecciones en los términos de la constitución de 1925, tendríamos que concluir, con el argumento de Cristi, que la dictadura se había arrogado el poder constituyente (porque la constitución de 1925 tampoco daba a los militares la competencia para decidir cuándo habría elecciones o quién detentaba el gobierno), cuando en realidad sólo habría sido una fugaz dictadura comisaria.

Aquí es importante notar que al decir que el poder constituyente de la junta no derivaba del pueblo, Cristi está haciendo una afirmación políticamente controvertida, en el sentido de que los militares y la derecha siempre alegaron que el golpe militar había sido una manifestación de la voluntad mayoritaria del pueblo chileno ${ }^{22}$. El hecho de que la afirmación sea políticamente controvertible nos da una invaluable pista respecto del tipo de alegato que la tesis de Cristi constituye: no es una alegato teórico, es decir, no es verdad en virtud de desprenderse de una correcta teoría del derecho (más los hechos relevantes) o del derecho, sino es uno político. El concepto mismo de poder constituyente, en cuanto a su operación e identificación concreta, no es un concepto teórico sino político; identificarlo y afirmar que ha actuado es una posición política, y por eso la pretensión de haberlo identificado o que ha actuado sólo puede fundarse en argumentos políticos, argumentos que se formulan precisamente hacia el pasado, como un esfuerzo de comprensión de una historia que se declara común.

Cuando Cristi apunta hacia el contenido de las reglas constitucionales de 1925 para fundar su tesis de que el régimen de Pinochet fue una dictadura soberana y no comisaria está usando, entonces, argumentos jurídicos para fundar una pretensión política. Está cometiendo (aunque es de suponer que con mejores intenciones) el mismo error que reprocha a Jaime Guzmán: su argumento es parte de una "maniobra política" destinada en definitiva a fundar su tesis de que en 1990 se inaugura en Chile la

implica nada similar. $Y$, como veremos, para encontrar la salida de este laberinto es necesario entender primero que lo que la dicotomía aquí rechazada implica es estrictamente falso: poder constituyente y poder constituido no son dos especies de un mismo género.

18 Guzmán, en Actas Constitucionales, sesión 14, p. 5 (cit. por Cristi, Jaime Guzmán, 86).

19 ibid, 87.

20 ibid.

21 Desde luego, la propia junta militar declaró en el bando $N^{\circ} 5$ (de 11 de septiembre de 1973) que asumía el poder "por el solo lapso en que las circunstancias lo exijan" ( $N^{0} 13$ ). Muchos no encontraton razón pata dudar de esta declatación inicial. Véase, por ejemplo, para el caso del ex-presidente Eduatdo Frei Montalva, Gazmuri, Eduardo Frei Montalva, 851-871.

22 Como lo mencionaba el mismo bando $\mathrm{N}^{\circ}$, según el cual el poder que las fuetzas armadas asumían estaba "apoyado en la evidencia del sentir mayoritario de la gran mayoría nacional" ( ${ }^{\circ} 13$ ). 
plena democracia. Para apreciar esto, sin embargo, debemos seguir el argumento cristiano hasta el final y preguntarnos no sólo qué ocurrió en 1973, sino también que ocurrió en 1988 y 89.

Desde 1982 hasta 1988, la agudización del movimiento de protesta, que culminaría con la derrota de ésta en el plebiscito de 1988, son manifestación, para Cristi, "del poder constituyente del pueblo"23. Como es sabido, después del triunfo del 5 de octubre la Concertación de Partidos por la Democracia negoció con Pinochet un paquete de reformas constitucionales que fueron aprobadas por abtumadora mayoría el 29 de julio de 1989. Estos hechos son para Cristi profundamente significativos, porque implican nada menos que la irrupción del pueblo que arrebata el poder constituyente de manos de la junta. Al principio del capítulo dedicado a la interpretación de estos hechos, sin embargo, Cristi cree necesario añadir una nota de cautela: "si bien es cierto que ese plebiscito [de 1989] y el sentido de las reformas que introduce, confirman que el poder constituyente ha sido retomado por el pueblo, esa toma de posesión es parcial. Persisten en el texto constitucional aprobado ciertas instituciones que no permiten la plena expresión del nuevo sujeto del poder constituyente"24.

Al decir que la recuperación por el pueblo del poder constituyente en 1989 es "parcial", Cristi parece sostener que el poder constituyente estaría dividido. Algunas de las "leyes constitucionales" de la llamada constitución de 1980 descansarían sobre el poder constituyente de la constitución de 1973, y otras descansarian sobre el poder constituyente de la constitución de 1989. Pero el propio Cristi sabe que no tiene sentido hablar de poder constituyente dividido. De hecho, es interesante oír lo que él nos dice respecto de otra situación en la cual se invocó la idea de poder constituyente dividido.

La situación es la Alemania de Weimar, en particular la dictación de la Etmächtigungsgesetz de 24 de Marzo de 1933. Esta ley de otorgamiento de poderes especiales (formalmente denominada "Ley para resolver la crisis sufrida por el pueblo y el Reich"), dictada por un Reichstag dominado por los nazis, declaró el estado de emergencia y confirió al gabinete de Hitler poderes legislativos. La peculiaridad de esta ley de poderes especiales es que ella confería al gabinete la facuitad de promulgar leyes constitucionales, reformando así la constitución. Carl Schmitt vió en estas arribuciones especiales dadas por la ley de 24 de marzo al gabinete la atribución a éste de "una porción del poder de dictar leyes constitucionales"25. Comentando esta tesis de Schmitt, Cristi sostiene que aún cuando decía que sólo una 'porción' del poder de reformar la constitución había sido conferido al gabinete, que él haya afirmado eso muestra temeridad irresponsable [reckless temerity]. Primero, Schmitt sabía perfectamente que el poder constituyente es indivisible (¿cómo podría ser de otro modo, si él fundaba la unidad política de un pueblo?). Entregar una porción de él es efectivamente entregarlo todo ${ }^{26}$.

Esta afirmación de Cristi merece dos observaciones. La primera es que al imputar "reckless temerity" a Schmitt por haber atribuido al gabinete parte del poder constituyente Cristi está dando por supuesto que la identificación del poder constituyente no son cuestiones teóricas sino políticas. En ottas palabras: que la descripción teórica de la situación creada por la Ermächtigungsgesetz no se limita a describir una realidad que existe con prescindencia de la teoría, sino que la reconfigura. Sólo asumiendo esta idea puede reprocharse por imprudente a quien ofrece una descripción teórica. La segunda quizás da la clave para entender las razones por las que Cristi no puede entender el proceso constitucional posterior a 1973: aquí Schmitt sostiene que la Ermächtigungsgesetz ha conferido al gabinete una porción del poder de dictar leyes constitucionales. Cristi lee esta afirmación en el sentido de que Schmitt reconoce al gabinete poder constituyente. Pero esto es claramente incorrecto. El poder de dictar leyes constitucionales es una forma de poder legislativo, y debe distinguirse categóricamente del poder constituyente, que es el poder para tomar las decisiones sobre la forma y modo de existencia

23 Cristi, Jaime Gurmán, 139.

24 ibid.

25 Cit. por Cristi, Cari Schmitt, 40. Véase adicionalmente Schmitt, Teoría de la Constizución, 126-133.

26 Cristi, Carl Schmitt, 44. 
de la comunidad política. El poder de dictar leyes constitucionales (poder constituido) puede ser dividido, condicionado, sujeto a condiciones u otras modalidades, etc. Nada hay de rato en esto. Es el poder constituyente (sobre el cual en los pasajes discutidos Schmitt nada dice) el que no puede ser dividido.

Pero si el poder constituyente (a diferencia del poder para dictar leyes constitucionales) no puede ser dividido, ¿cuál puede ser el significado de la afirmación de que en 1989 el pueblo accedió a "una porción" del poder constituyente? ¿Qué sentido tiene decir que en 1989 el pueblo chileno "tomó posesión parcial" del poder constituyente? Con la lógica con la que Cristi enjuicia a Schmitt podemos decir: como el poder constituyente es indivisible, quien retiene una porción de él lo retiene todo. $\mathrm{O}$ también: como el poder constituyente es indivisible, quien accede a una parte de él accede a todo él. Cristi, sin embargo, cree poder mantener una posición intermedia, la misma que él niega a Schmitt: Sólo en 1988 puede decirse que comienza la transición a la democtacia. Cuando se manifiesta plenamente el poder constituyente del pueblo y se extingue el de la Junta de Gobienno hay plena democracia instantánea (aunque la plenitud sea, en ese momento, en principio solamente, y no tenga efectividad real como lo prueba el hecho de que tanto la Junta de Gobierno como Pinochet continúen en el poder hasta marzo de 1990) ${ }^{27}$.

Este pasaje demuestra lo insostenible de la posición de Cristi: ¿qué, precisamente, quiere decir que el poder constituyente se manifieste "plenamente" pero que esa plenitud sea "en principio solamente"? ¿En virtud de qué podemos decir que la plenitud del poder constituyente del pueblo sea "en principio solamente"? Cristi a veces dice que ello es demostrado por el hecho de que las mismas personas se mantuvieron en posiciones de poder (Pinochet y la junta de gobierno, que retuvieron sus posiciones de poder hasta marzo de 1990 y continuaron después de esa fecha como comandantes en jefe de sus respectivas armas), y otras veces parece afirmar que lo que importa no son las personas sino las instituciones, como cuando dice que la toma de posesión del.poder constituyente por el pueblo fue parcial porque "persisten en el texto constitucional aprobado ciertas instituciones que no permiten la plena expresión del nuevo sujeto del poder constituyente"28. Esto es también ininteligible. El texto constitucional no es obstáculo, no puede ser obstáculo para la expresión del poder constituyente.

En el capítulo 3 de la Teoría de la Constitución, Schmitt afirma que "la constitución en sentido positivo surge mediante un acto del poder constituyente"29, un acto que "constituye la forma y modo de la unidad política, cuya existencia es anterior"30. El contenido de este acto es "la decisión política del titular del poder constituyente, es decir, del pueblo en la democracia y del monarca en la monarquía auténtica" "31. Sólo con una idea de este tipo es posible, como hemos visto, distinguir entre leyes constitucionales y constitución: la constitución es la decisión política fundamental, las leyes constitucionales son otras reglas que se incorporan al texto denominado "constitución". Un cambio de leyes constitucionales no significa un cambio de constitución, un cambio de la constitución no necesariamente implica un cambio de las leyes constitucionales. Cristi sostiene que en 1973 hubo en Chile un cambio de constitución, aunque algunas leyes constitucionales sobrevivieron. En 1989, según Cristi, cambió la constitución aun cuando muy pocas leyes constitucionales cambiaron.

Aquí la distinción entre constitución (= decisión fundamental sobre la forma y modo de existencia política) y leyes constitucionales ( = normas que no contienen esa decisión pero están dotadas, en términos formales, de "rango constitucional" en cuanto a sus requisitos de aprobación, modificación y derogación) se hace crucial: ¿qué fue lo que cambió en 1989?

27 Cristi, Jaime Guzmán, 142.

28 cit. supta, n. 5.

29 it. Supra, n. 25.

30 ibid, 46.

31 ibid, 47. 
Jurídicamente la respuesta sólo puede ser: nada ${ }^{32}$. La constitución de 1980 fue reformada siguiendo rigurosamente el mecanismo previsto en ella para su reforma, por lo que no hay cuestión de la continuidad jutídica de la constitución de 1980 con lo que ocurrió después de 1989. Si usáramos el mismo argumento que usa Cristi para afirmar que el golpe de estado de 1973 fue la irrupción en la historia chilena de una dictadura soberana (porque no fue ejercicio de potestades constituidas), debemos concluir que hay continuidad perfecta entre la constitución de 1980 y la llamada "constitución de 1989" (porque ahora sí hubo ejercicio de potestades constituidas), y que por consiguiente ambas - que en rigor no son dos sino una constitución - son reconducibles al mismo poder constituyente. Pero Cristi no está dispuesto a seguir su propio argumento: ahora sostiene que el problema de si la constitución de 1980 fue o no legitimada democráticamente en 1988 (o 1989, o 1990), es decir, si en 1989 se ejerció un nuevo poder constituyente, "requiere ser determinado políticamente, en el sentido schmittiano del término". Pero a continuación Cristi bota la escalera y queda colgando de la brocha, cuando afirma que "por eso escapa a los límites de este trabajo"33.

No escapa a los límites de su trabajo, según Cristi, determinar si la constitución de 1989 descansa o no sobre el poder constituyente del pueblo; sí escapa determinar si la constitución que surge del plebiscito de 1989 está legitimada democráticamente. Pero éstas no son dos preguntas diferenciables, y como no lo son, la afirmación de Cristi de que la constitución de 1989 es expresión del poder constituyente "pleno" del pueblo no es políticamente vacía. Implica imputarle al pueblo de Chile las leyes constitucionales que quedaron vigentes después de esa reforma, por lo que implica imputarle al pueblo (al menos hasta la dictación de la ley 20050, en 2005, aunque esto supone una comprensión del significado político de esta reforma sobre el cual no puedo extenderme aquî) una democracia "protegida", con inamovilidad de los comandantes en jefe de las fuerzas armadas, consejo de seguridad nacional, senadores designados y una composición determinada del tribunal constitucional, altos quorum de reforma legal, etc. El efecto político de la afirmación de Cristi, de que ya no existe la constitución de 1980 y que vivimos bajo el imperio de la de 1989, es precisamente hacer lo que Cristi dice que no quiere hacer: dar a la constitución de 1980 (incluso a sus cláusulas no reformadas) legitimidad democrática, en tanto expresión del poder constituyente del pueblo.

Esos problemas, sin embargo, son demasiado importantes para dejarlos de lado. En realidad, hay pocas cuestiones más importantes si de lo que se trata es de entender el momento constitucional en el que nos encontramos (ahora). Pero, chay algo más que decir si lo que debe ser determinado políticamente es ignorado? La alternativa es obvia: podemos intentar entenderlo jurídicamente. Pero la perspectiva que el derecho adopta es severamente limitada, en el sentido de que atiende a lo que es jurídicamente, no políticamente, relevante. Lo jurídicamente determinante es la forma, que no hace distinciones entre constitución y leyes constitucionales. En otras palabras: jurídicamente hablando no puede haber distinción entre constitución y ley constitucional. Esta observación puede resultar extraña, en particular desde que hemos visto que la distinción entre constitución y ley constitucional es el inicio de la teoría constitucional; la manera en que estas dos observaciones se compatibilizan es simplemente aceptando que la idea de una teoría jurídica de la constitución es una imposibilidad conceptual: la teoría de la constitución sólo puede ser una teoría política de la constitución ${ }^{34}$. O mejor dicho, una teoría jurídica de la constitución es una teoría de lo constituido, es decir, del contenido no constituyente del texto constitucional. Por eso Cristi, cuando adopta la perspectiva del derecho, no puede entender lo constituyente, y lo interpreta como se interpreta lo constituido.

$32 \mathrm{Nada}$, por supuesto, en el sentido en que nos interesa aquí. El contenido de algunas leyes constitucionales cambió, desde luego. 33 Cristi, Jaime Gurmán, 100.

34 Por eso Carrió sostenía que la idea del poder constituyente violaba los límites del lenguaje normativo (Carrió, "Sobre los límites del lenguaje normativo"). Esto muestra algo que hoy parece olvidarse, que la constitución es "derecho" en un sentido diferente al de una ley. Véase Atria, F: "El derecho y la contingencia de lo político". Al final de este artículo veremos que esto es una manifestación de la irreducibilidad de la política al derecho: ella es reflexiva, éste es excluyente. 
Para mostrar lo anterior podemos considerar más detenidamente un problema al que ya hemos hecho alusión: ¿cómo saber si una constitución x y una constitución y son en realidad la misma constitución, que y es en realidad $x$ aunque reformada? ¿Cómo distinguir, en otras palabras, entre supresión y reforma de la constitución? , la respuesta a esta pregunta depende del modo en que ella es entendida. Si la pregunta es entendida jurídicamente, la respuesta sólo puede mirar a los rasgos formales de ambas constituciones. Como siempre, para apreciar la respuesta que el derecho da a un problema no hay nada mejor que recurrir a Kelsen:

El principio de que la norma de un orden jurídico vale durante todo el tiempo que transcurra hasta que su validez no sea terminada en la manera determinada por ese orden jurídico, o hasta que sea reemplazada por la validez de otra norma de ese orden jurídico [...] se aplica a un orden jurídico estatal con una limitación altamente significativa. No tiene aplicación en caso de revolución. Una revolución, que abarca también el golpe de estado, es toda modificación no legítima de la constitución - es decir, no efectuada conforme a las disposiciones constitucionales - o su reemplazo por otra. Visto desde un punto de vista jurídico [...] lo decisivo es que la constitución válida sea modificada de una manera, o reemplazada enteramente por una nueva constitución, que no se encuentra prescrita en la constitución hasta entonces válida ${ }^{35}$.

Nótese cómo lo que nos importa cuando entendemos la pregunta en su sentido político es estrictamente invisible para el derecho: no hay diferencia entre constitución y leyes constitucionales, no hay diferencia entre dictadura comisaria y dictadura soberana. Cuando Cristi asume esta perspectiva le resulta crucial quiénes eran los que dictaron (e.g.) el bando $\mathrm{N}^{\circ} 5$ o el decreto ley 1 (i.e. si tenían o no atribuciones para hacerlo conforme a la constitución de 1925), cuáles eran sus declaraciones al momento de hacerlo (i.e. si reconocían o no la constitución de 1925 como tal), etc. Pero el problema que Cristi se ha fijado a sí mismo, el de entender el proceso constituyente posterior a 1973, no es un probiema estrictamente jurídico, como hemos visto que él mismo reconoce cuando se enfrenta a lo que él denomina la "constitución de 1989", sino un problema de asignación de significado político a ciertos hechos. Para esta asignación, entonces, Cristi oscila entre la perspectiva jurídica (cuyo problema central es el de establecer la continuidad o discontinuidad formal entre las leyes constitucionales de 1925, 1973, 1980 y 1989) y la cuestión política (cuya pregunta central es quién tomó la decisión sobre la forma y modo de existencia de la comunidad política chilena), entre un criterio jurídico, formal, y otto político, material. La oscilación de Cristi En cuanto a la naturaleza del problema (jurídico o político) tiene un estrecho correlato en su uso de argumentos para establecer sus conclusiones: a veces ellos son argumentos jurídicos para fundar sus atribuciones de significado políticas, y otras veces son argumentos políticos para fundar sus atribuciones jutídicas de significado.

Cristi hace lo primero cuando dice que la junta militar en 1973 asumió el poder constituyente originario, porque actuó fuera de las competencias que le entregaban las reglas de la constitución de 1925; hace lo segundo cuando se refiere a la "constitución de 1989". En ese año la irrupción del poder constituyente del pueblo habría destruido la constitución de 1980. Como en 1973, subsistirían algunas leyes constitucionales, pero no la constitución: La constitución chilena actual [dice Cristi en 2000], y las instituciones que valida, no corresponden a la constitución de 1980. Por tener un titular o sujeto de poder constituyente distinto del que se expresó en 1980, debería poder decirse que la actual es una constitución distinta, análoga materialmente, pero no en su espíritu, a la de 1980 [... .] Sólo esta admisión concuerda con la plena transición democrática ocurrida al término de la dictadura ${ }^{36}$.

35 Kelsen, Teoría Pura, 217-18 (el destacado es agregado). Es interesante notar que Alf Ross se niega a adoptar la perspectiva del derecho tratándose de la reforma constitucional, y por eso concluye que la reforma constitucional es conceptualmente imposible (véase Ross, Sabre el Derecho y la Justicia, 79ss). Hart, característicamente, no nota el problema (Hart, "Self-referring laws"). 36 Cristi, Jaime Gurmán, 147 (cursivas agregadas). 
Aquí Cristi abandona la perspectiva jurídica que utilizó para caracterizar de dictadura soberana a la de Pinochet y adopta una perspectiva política: ¿qué otra cosa puede significar la referencia a "el espíritu" de la constitución si no es la interpretación política de los hechos de julio de 1989? Si miramos lo ocurrido en esos días con ojos kelsenianos ("desde un punto de vista jurídico"), debemos concluir que hay continuidad perfecta entre la constitución de 1980 y la de 1989. En rigor, que ésta no existe como distinta de la anterior. ¿̨Por qué Cristi no llega a esta sencilla conclusión? Mi impresión es que la respuesta está en que él no quiere ofrecer una interpretación escéptica de la transición chilena, una en la cual la transición todavía no ha comenzado (el mismo argumento kelseniano setía aplicable a todas las reformas posteriores, incluida la contenida en la ley 20050). Eso lo lleva a la extraña tesis de que en 1989 itrumpió de nuevo el poder constituyente originatio, aunque sólo parcialmente. Esta cuestión, probablemente la más interesante del texto de Cristi pero al mismo tiempo la más oscura, es la que debe ocuparnos a continuación. Esto nos permitirá apreciar la forma general del argumento ofrecido en esta sección y, así, radicalizarlo.

(Parte de) la razón que puede explicat la confusión de Cristi es su rápida identificación del poder constituyente que se manifestó en 1973 con la junta militar. Efectivamente, en términos formales la junta era la que aparecía detentando el poder constituyente, y lo retuvo (sujeto a ratificación plebiscitaria) incluso después de 1980 (hasta el 11 de marzo de 1990, para ser más exactos) ${ }^{37}$. ¿Pero por qué han de ser los términos formales los que decidan una cuestión política? Una posible respuesta es que esto es "realista", en el sentido de que mira a quién tenía el poder (de nuevo, los bombarderos sobre La Moneda, los 18 mil soldados en las calles de Santiago los días 2 y 3 de julio de 1986), pero no es en absoluto realista aceptar sin más la pretensión de la junta de gobierno de que ella detentaba el poder constituyente. De hecho, sabemos que en términos "realistas" no todos los miembros de la junta militar eran iguales, y no todas las ramas de las fuerzas armadas tenían el mismo control sobre los medios de destrucción. Ambas cosas son demostradas por casos como el del comandante en jefe de la fuerza aérea, quien fuera purgado de ésta a fines de los $70^{38}$. Si fuéramos verdaderamente realistas, entonces, tendríamos que preguntarnos quién era el que verdaderamente tenía el poder. Y cuando nos preguntamos quién tenía verdaderamente el poder se abren una serie de cuestiones ante las cuales la respuesta formal (i.e. el contenido del bando $\mathrm{N}^{\circ} 5$ o del decreto ley 27 o de la disposición 21 transitoria de la "constitución") es obviamente inadecuada. Incluso aceptando que Pinochet tenía control sobre los medios de destrucción y que el ejército tenía armas suficientes para imponer su voluntad sobre las otras ramas de las fuerzas armadas, no podemos de eso concluir que tenía el poder constituyente.

El punto ahora no es identificar el "soberano" del 11 de septiembre de 1973, sino llamar la atención sobre el hecho de que, con su aceptación incuestionada de la propia declaración de la junta arrogándose el poder constituyente, Cristi deja de lado algunas de las más interesantes cuestiones respecto de la historia política de Chile en el siglo XX, especialmente en la segunda mitad de éste. Ello porque desde luego el problema de la identificación del poder constituyente de la llamada "constitución de 1980" puede ser radicalizado, esta vez respecto de la constitución de 1925.

No me queda claro, de hecho, qué es lo que lleva a Cristi a aceptat como dato de la causa que el poder constituyente del pueblo era el que sostenía a la constitución de 1925. Las formas en que el poder constituyente del pueblo se ejerce, nos recuerda Schmitt, no pueden ser caracterizadas formalmente, porque "el pueblo, como titular del poder constituyente, no es una instancia firme, organiza-

37 Véase la disposición $21^{2}$ transitoria letra c de la constitución de 1980 (las disposiciones transitorias de la constitución eran las que eran aplicables entre el 11 de marzo de 1989 y el 11 de marzo de 1990): "Ta Constitución sólo podrá ser modificada por la Junta de Gobierno en el ejercicio del Poder Constituyente. Sin embargo, para que las modificaciones tengan eficacia deberán ser aprobadas por plebiscito, el cual deberá ser convocado por el Presidente de la República".

38 vid. Cavallo et al., La Hzistoria Oculta, 304-320. 
da"39. La voz del pueblo, en consecuencia (o del poder constituyente en general) sólo puede ser identificada de manera retrospectiva. Schmitt enumera algunas de las formas a través de la cual la voz del pueblo se ha dejado oír: "un procedimiento de votación secreta o elección secreta"40, la aclamación ${ }^{41}$, o lo que se ha constituido como la práctica normal de las democracias constitucionales, la "llamada asamblea nacional constituyente democrática, es decir, elegida según los postulados fundamentales del sufragio universal e igual, como procedimiento 'democrático' reconocido"42.

De todas las anteriores (que, por lo dicho, no pueden aspirar a ser una enumeración exhaustiva), sólo parece posible considerar la posibilidad de que la constitución de 1925 haya sido aprobada por el pueblo por votación. Pero las condiciones en las que se realizó el plebiscito constitucional de 1925 fueron altamente problemáticas, por lo que entender sin más que en él se expresó sin vicios la voluntad del pueblo es altamente problemático ${ }^{43}$.

Pero cuando empezamos a formular este tipo de objeciones a una constitución como la de 1925 pronto resulta evidente que hemos tomado el camino equivocado. Para responder la pregunta que nos estamos formulando (quién detentaba el poder constituyente bajo la constitución de 1925) los detalles de la aprobación de la constitución de 1925 son ahora irrelevantes (no eran necesariamente irrelevantes en, digamos, 1935). Del mismo modo, que la constitución norteamericana de 1786 haya sido pactada por un grupo de dueños de esclavos blancos, protestantes y ricos que abusaron de su mandato no nos dice mucho sobre la práctica constitucional norteamericana. Lo que es relevante es la "forma y modo de existencia" que adoptó la comunidad política norteamericana desde 1786 o la chilena entre 1925 y 1973. Y si éste es nuestro problema, entonces nuestra respuesta podría ser, e.g. que esa práctica estuvo caracterizada por una desarrollo progresivo de la conciencia política del pueblo, tal que precisamente cuando el pueblo reclamó el poder constituyente, y se arrogó la facultad de revisar la "forma y modo" de existencia política (en especial el rol que dentro de ella correspondería al derecho de propiedad privada) el derecho fue intertumpido: el régimen de la constitución de 1925 sólo habría funcionado, en esta interpretación, mientras el autogobierno democrático no pusiera en cuestión las cuestiones centrales de distribución del poder: el régimen político chileno estaba estructurado para bloquear la posibilidad del cambios profundos. Estaba organizado para favorecer una política de cambios graduales y negociados entre las élites parlamentarias y partidarias ${ }^{44}$.

No pretendo ofrecer argumento alguno para sostener esta tesis, porque no la estoy defendiendo sino enunciando, con la esperanza de que su enunciación mostrará el tipo de argumentos que es necesario ofrecer antes de decir que el poder constituyente bajo la constitución de 1925 lo tenía el pueblo, lo que a su vez nos muestra el tipo de pregunta que estamos formulando. Tampoco estoy insinuando que no sea posible presentar un argumento que justifique esa conclusión. Sólo estoy indicando que la identificación demasiado apresurada que hace Cristi de los poderes constituyentes que han actuado en la historia de Chile en el siglo XX (el pueblo en 1925, la junta militar en 1973, el pueblo nuevamente en 1989) pasa por sobre todas estas cuestiones sin siquiera reconocer su existencia.

De hecho, y dejando atrás la postura escéptica esbozada tres párrafos más atrás, Cristi no deja espacio para la que a mi me parece la hipótesis más razonable para interpretar la historia política de Chile entre 1925 y 1973: que no fue el poder constituyente del pueblo el que se manifestó en 1925,

39 Schmitt, Teoria de la Constitución, 99.

40 ibid, 100.

41 Schmitt creía que la aclamación no era sólo una forma más de expresión de la voluntad del pueblo, sino su forma natural (ibid). Para autores como Bruce Ackerman esta identificación de la forma "natural" de actuación es repulsiva (véase Ackerman, La Politica del Diálogo Liberal, 150). Esto en realidad confirma la tesis que estoy intentando desarrollar, porque muestra que la idea substantiva de qué cuénta como el pueblo alemán se refleja en la manera en que éste actúa.

42 Schmitt, Teoria de la Constitución, 101.

43 Véase, en general, Wood, El Plebiscito Constitucional de 1925, 61-94.

44 Moulian, La Forja de Ilusiones. El sistema de partidos, 1932-1973, 49. 
pero que la república a la que dicha constinución dio forma y modo de existencia debe ser entendida como un proceso por el cual el pueblo se afirma progresivamente como titular del poder constituyente en desmedro del poder constituyente minotitatio que la impuso (cuya identificación precisa no nos interesa ahora). Para permitir una posición como ésta es necesario entender el problema de la identificación y atribución del poder constituyente es un problema de interpretación política, y como la interpretación de una práctica es una interpretación de esa práctica, el modo (contingente) en que ella se ha desarrollado, su historia, puede hacer más o menos adecuadas diferentes interpretaciones. Eso nos permite discutir el problema del poder constituyente sin tener que estar escarbando los detalles del último momento reconocido "oficialmente" como constituyente, por remoto que sea. Peto Cristi no cree que esto pueda ser así, porque él cree que las cosas se dan en términos inmediatos: El poder constituyente, cuando es invocado, opera normalmente con la celeridad instantánea del rayo. Por ello puede decirse que fue instantánea y completa la transición a la dictadura en 1973. Si se aplica esa noción a la transición democrática de 1988, habría que decir lo mismo, que la transición también fue instantánea, completa y no gradual. El poder o potestad constituyente se trasladó, en esta ocasión, de la Junta de Gobierno al pueblo chileno ${ }^{45}$.

$\mathrm{El}$ argumento es evidentemente falso. Que el paso de x a y sea inmediato no quiere decir que el paso de y a $\mathrm{x}$ deba ser igual de inmediato, como sabe cualquiera que haya intentado armar un castillo de naipes (o que recuerde lo ocurtido el otro 11 de septiembre). Lo que opera "como el rayo que rasga el seno de una nube" (la imagen es de Donoso Cortés) es la interrupción de lo jurídico (no soy capaz de entender la afirmación de Cristi de que el poder constituyente opera "cuando es invocado", y menos que así lo hace "normalmente". El poder constituyente "opera" cuando opera sin que sea necesario ni suficiente que sea invocado). Esta decisión, como dice Schmitt, "se libera de todas las trabas jurídicas y se torna absoluta, en sentido propio"46. La razón por la cual la interrupción de la constitución opera de este modo es que el acto mediante el cual ella se afirma ella será siempre ilegal. En la medida en que un acto tiene la entidad suficiente para desafiar la normalidad del orden jurídico, sólo hay dos posibilidades: reafirmación de la normalidad (y clasificación del acto como delito) o interrupción de lo universal (jurídico). Un intento de interrupción de lo jurídico sólo puede ser público, y por eso exige una respuesta inmediata: si los que dieron la orden de bombardear La Moneda no son sancionados como autores de un delito, entonces el orden jurídico queda interrumpido. La interrupción de lo jurídico, en consecuencia, si puede operar con la rapidez del rayo.

La razón por la que la interrupción de lo jurídico opera de ese modo es que para destruir el derecho basta la violencia. La violencia tiene, en efecto, la capacidad de destruir el poder. Pero (el control de los medios de) la violencia, como decía Arendt, no es suficiente para constituir poder. Entre destrucción de una constitución y creación de una nueva, entonces, hay una asimetría, y es esta asimetría la que es ocultada por la caracterización schmittiana de "destrucción" de la constitución: ignora la posibilidad de la des-constitución del poder, de la tiranía ${ }^{47}$. La fuerza, la violencia, puede destruir una constitución pero no basta para constituir una nueva. Por eso he hablado de "interrupción" y no de "destrucción" o "suspensión" de lo jurídico. La violencia que intertumpe el detecho puede ser violencia que destruye el derecho o violencia que lo suspende. Pero para rescatar la extraordinaria relevancia de esta idea es necesario atender a las relaciones entre poder y violencia y su correlato político, dictadura y tiranía.

45 Cristi, Jaime Gužnán, 141

46 Schmitt, Teología Politica, 24.

47 Véase supra, n. 24. 


\section{Entre tiranía y dictadura}

Si las consideraciones anteriores son correctas, no puede ser correcto hablar de la "constitución de 1973", instantáneamente nacida de las bombas sobre La Moneda. El poder constituyente no es ni puede ser puro y arbitrario poder, porque es constituyente y constituir significa dar forma a lo informe: "un poder absoluto, y que quiera seguir siendo absoluto" no puede constituir nada ${ }^{48}$. Un poder absoluto es un poder para el cual todas las posibilidades están abiertas. Es pura potencia, es decir, permanente posibilidad de ser o no ser. Por eso es que el momento de interrupción del derecho deja todo en el aire, abre todas las posibilidades. La interrupción de todo aquello que produce mediación en el ejercicio del poder hace que todo se haga contingente. Es, como veremos a su debido tiempo, el momento absoluto en términos de Kierkegaard. Pero la contingencia de la interrupción del derecho puede llevar al restablecimiento o recuperación de la normalidad. En una iluminadora analogía elaborada por Zenon Bankowski,

En una versión de la teoría del universo del 'Big Bang', uno podría decir que el universo se inicia con la explosión de una singularidad. Esa explosión es arbitraria - no hay razón para ella. Sin embargo la explosión lleva dentro de sí, en su propio desarrollo, la racionalidad en la forma de leyes científicas y tiempo. La causalidad y toda la racionalidad científica están inscritas en esa explosión y se despliegan desde ella. La racionalidad científica puede originarse en un acto arbitrario, pero eso no la hace irracional porque lo racional está inscrito en lo arbitrario y viceversa ${ }^{49}$.

Entender que la explosión original es arbitraria implica entender que la racionalidad que lleva dentro de sí la lleva contingentemente dentro de sí, que las cosas podrian haber sido de otro modo. Entender retrospectivamente el orden posterior a la interrupción del derecho como fundado en ella es entender que la interrupción fue suspensión y no destrucción del derecho. Es en este caso que hablamos de poder constituyente. La arbitrariedad de la explosión inicial significa que ella es pura potencia, que deja todas las posibilidades abiertas. Constituir significa actualizar algunas, negando otras: Para que la potencialidad retenga su propia consistencia y no desaparezca inmediatamente en actualización, es necesario que la potencialidad pueda no actualizarse, que la potencialidad constitutivamente sea potencialidad de no (ser o hacer) o, como dice Aristóteles, que la potencialidad sea también impotencialidad ${ }^{50}$.

Pero la mantención constante de la potencialidad de no-ser impide constituir. Esto nos permite trazar la distinción entre tiranía y dictadura a la que ya hemos aludido: la tiranía es una fuerza en potencia que se niega a negar sus posibilidades no actualizadas, la dictadura es una fuerza en potencia que por la vía de constituir va progresivamente negando su potencialidad de no-ser. La tiranía, entonces, no es capaz de constituit.

La titanía (o despotismo) es la forma de gobierno basada en el temor: el poder inmenso del príncipe pasa por entero a aquellos a quienes lo confía. Las personas capaces de estimarse mucho a sî mismas podrían fácilmente provocar revoluciones. Es preciso, pues, que el temor tenga todos los ánimos abatidos y extinga hasta el menor sentimiento de ambición ${ }^{51}$.

Por eso la titanía, a diferencia de la dictadura, lleva en sí el germen de su propia destrucción: “el principio del gobierno despótico se corrompe sin cesar, lleva la corrupción en su naturaleza" ${ }^{52}$. La

48 Böckenförde, "El poder constituyente del pueblo", 176.

49 Bankowski, Living Lanfully, 100. Este argumento desbarata la objeción de MacIntyre a Kierkegaard en MacIntyre, After Vintue, $42 \mathrm{~s}$

50 Agamben, Homo Sacer, 45. Véase en general ibid, 46ss, donde Agamben discute la noción aristotélica de potentia, que "legó el paradigma de la soberanía a la filosofía occidental'.

51 Montesquieu, Espinitu de las Leyes, 4.9

52 ibid, 8.10 
razón por la cual la tiranía es intrínsecamente inestable surgirá más adelante, cuando hablemos de la relación entre violencia y poder: la tiranía se basa en la violencia, y la violencia es la negación del po$\operatorname{der}^{53}$.

No hay, entonces, oposición entre constitucionalismo y dictadura, aunque hay oposición entre constitucionalismo y tiranía. En realidad, lo que se sigue es más categórico: que hay oposición entre derecho y tiranía como no hay entre derecho y dictadura. Que no haya oposición entre constitucionalismo (derecho) y dictadura no quiere decir que debamos celebrar las dictaduras (esta lectura del argumento de este artículo debe ser sistemáticamente rechazada). Lo que quiere decir es que el derecho (la constitución) supone la dictadura, al menos como posibilidad eventual. Negar la implicación recíproca de constitución y dictadura es perder de vista la contingencia de la comunidad política. Esta ceguera a ese momento es característico del liberalismo, como lo notó Carl Schmitt en las notables páginas finales de La Dictadura: En la transición del absolutismo regio al estado de derecho burgués se presupuso, como evidente por sí mismo, que en lo sucesivo estaba asegurada de una manera definitiva la unidad solidaria del estado. La seguridad podía ser alterada por tumultos y motines, pero la homogeneidad no estaba amenazada seriamente por los agrupamientos sociales dentro del Estado. Si un individuo o un tropel de individuos alteran el orden jurídico, ésta es una acción cuya reacción puede ser calculada y regulada previamente, del mismo modo que la ejecución procesal civil y penal delimita con exactitud la esfera de sus medios de poder en lo cual radica la regulación jurídica de su procedimiento. Mediante una limitación semejante tal vez se pone en peligro el fin a alcanzar. Si se agotan los medios de ejecución permitidos, falla la coacción contra el culpable, como expresara Binding, cuyo vigoroso sentido jurídico no puede menos que asombrar aquí: 'el culpable escarnece el derecho'. Pero este escarnio no amenaza la unidad del estado ni la existencia del ordenamiento jurídico. La ejecución puede ser regulada en un procedimiento jurídico, siempre que el adversario no sea una potencia que ponga en peligro esa misma unidad ${ }^{54}$.

Esta presuposición continua impidiéndonos comprender cuestiones como el proceso constitucional chileno después de 1973. Robert Barros, en su libro sobre la junta militar y la constitución de 1980, encuentra "sorprendente e impactante" la conclusión a la que llega de que un régimen autocrático puede ser limitado por una constitución de su propia creación ${ }^{55}$. Por supuesto, la denominación "autocrático" evita la distinción entre dictadura y tiranía, la que es notoriamente ignorada por Barros a pesar de que ella aparece, sin ser reconocida, una y otra vez en su libro. Por ejemplo, Barros enumera una serie de "paradojas" que son sugeridas por la estructura y el contenido de la constitución de 1980: ¿por qué promulgar una constitución, en particular si los militares aparentemente no tenían ninguna intención de embarcarse en una transición? [...] ¿Por qué el dualismo entre los artículos permanentes y los transitorios? Si la constitución era un mero ejercicio de legitimidad, ¿por qué preocuparse en forma tan meticulosa del contenido de los artículos permanentes? Dada la reticencia de los participantes a revelar las diferentes creencias, estrategias y jugadas cuya interacción culminó en la decisión de promulgar la Constitución, podría resultar imposible responder a cabalidad todas estas preguntas ${ }^{56}$.

Todas estas "paradojas" dejan de serlo cuando entendemos que lo que las origina no es nuestro desconocimiento de la discusión al interior de la junta militar, o la inexistencia de actas de esta última, como parece creerlo Barros, que parece entender que la solución a estas preguntas está en lo que los militares del caso pensaban que estaban haciendo. En definitiva Barros adopta la posición de lo que más adelante veremos que Kierkergaard llamaba los "profesores" (docenter) y, juzgando por el resultado, entiende que la interpretación correcta del régimen es la que tenía el propio régimen, y entiende

53 Véase Arendt, Human Condition, $\$ 28$.

54 Schmit, La Dictadura, 261.

55 Barros, La Junta Militar, 18.

56 ibid, 215. El destacado es de Batros. 
que la interpretación que en definitiva primó como autocomprensión del régimen es la que verdaderamente éste siempre tuvò.

Barros entiende el problema incorrectamente, quizás en parte porque la manera en que la ciencia política entiende la política le impide entender la política. Ello porque no puede haber "ciencia" de lo constituyente. Esto se hace especialmente evidente cuando, al principio de su libro, Barros vuelve sobre el viejo problema de la ilimitabilidad jurídica de la soberanía. Sus puntos de partida son, natutalmente, Bodino y Hobbes: Tanto para Hobbes como para Bodino el carácter definitivo inherente a la soberanía hace estructuralmente imposible imponetle limitación legal alguna a la cúspide de la jerarquía legal: si ascendemos por la jerarquía legal rastreando poderes y autoridades, encontraremos un punto donde el sistema de toma de decisiones se cierra en una autoridad final más allá de la cual no hay apelación posible ${ }^{57}$.

Esto crea un problema para las "dictaduras" (uso las comillas cuando adopto el sentido indiferenciado de Barros), en particular para la idea de una dictadura que dicta normas que limitan su poder. ¿Cómo podría ella limitarse y, así, constituir? Al principio de su estudio, Barros cuidadosamente distingue los límites normativos (jurídicos) de los límites materiales, cuya confusión puede "llevar a los lectores a pensar equivocadamente que el autoritarismo limitado plantea relativamente pocos problemas" ${ }^{\prime 5}$. Veremos que el problema es otro: es que la distinción entre ellos puede llevat al analista a creet equivocadamente que, en los términos de Barros, cualquier tipo de régimen que no sea tiránico plantea relativamente pocos problemas.

Por supuesto no está en la idea de Hobbes ni en la de Barros que el poder absoluto del soberano no admite limitación material alguna. Peto la pregunta relevante es, en una situación como la chilena después de 1973, ¿cómo pueden ellos distinguirse? Es difícil ver qué es lo que caracteriza a un límite jurídico por oposición a un límite material. El propio Bartos, después de haber sostenido que ambos debían ser distinguidos (aunque sin proveer de un criterio pata distinguirlos) se ve en la imposibilidad de mantener la distinción y reduce los límites jurídicos a límites políticos. Así, por ejemplo, al comentar la significación del decteto ley 788 (conforme al cual la junta de gobierno podía reformar la constitución sólo si lo declaraba expresamente): Este mero requisito formal no eta insignificante. Las modificaciones expresas obligaban a los miembros de la junta a hacer consideraciones de prudencia política que no se tomaban cuando se trataba de actos de legislación simple, pues las modificaciones expresas a la constitución tendían a llamar la atención nacional e internacional ${ }^{59}$.

Barros parece no notar que todas las restricciones institucionales tienen, a cierto nivel, el mismo carácter. Esto no muestra que es una ilusión creer que puede haber una "dictadura" limitada jurídicamente, sino muestra que las limitaciones jutídicas de los regímenes democtáticos son igualmente problemáticos. De hecho, la idea misma de poder constituyente surgió como una idea democrática, no dictatorial: "no solamente la nación no está sometida a una constitución sino que no puede estarlo, no debe estatlo, lo que equivale a decir que no lo está" 60 . Adelantando algo atgumentos a ser desarrollados después, podemos ver aquí la naturaleza paradójica del poder constituyente: sólo es constituyente en la medida en que da origen a lo constituido, y sólo puede dar origen a lo constituido si es capaz de negarse, pero no puede negarse. El peligro, entonces, no es que la confusión de límites materiales y jurídicos lleve a pensar que la idea de autotitarismo limitado es poco problemática, sino que la separación formalista de ambos lleva a pensar que la idea de constitución (autoritaria o democrática) no es problemática.

$57 \mathrm{ibid}, 40 \mathrm{~s}$

58 ibid, 46.

$59 \mathrm{ibid}, 134 \mathrm{~s}$.

60 Sieyès, ¿Qué es el Estado Llano?, 107. 
Para los que llegan a este problema desde la teoría del derecho, la necesaria ilimitabilidad jurídica de la soberanía es una tesis que puede ser tranquilamente ser abandonada desde que H L A Hart la refutó en El Concepto de Derecho. Hart hace lo que sugiere Barros, y asciende por la jerarquía del derecho "rastreando" un poder jurídicamente ilimitado. En definitiva lo encuentra en "el electorado": Puede considerarse al electorado como una "legislatura extraordinaria y ulterior", superior a la legislatura ordinaria que está jurídicamente "obligada" a observar las restricciones constitucionales; en caso de conflicto, los tribunales declararán inválidas las leyes de la legislatura ordinaria. Aquí, pues, es en electorado donde se encuentra el soberano libre de toda limitación jurídica que la teoría exige ${ }^{61}$.

Pero por supuesto, "el electorado" no es un hecho bruto, sino un hecho institucional, es decir, algo que existe en virtud de reglas. A esto, me imagino, se refiere Bartos cuando citando precisamente a Hart (y Kelsen) sostiene que ellos afirman que la autoridad final "puede corresponder a un conjunto de leyes". La versión de Barros no es exacta, porque la autoridad final no es un conjunto de normas sino un hecho institucional, es decir, un hecho constituido por reglas ("secundarias"). Esas reglas constituyen la autoridad final y fijan las condiciones bajo las cuales una determinada voluntad le es imputable. Esta solución no es suficiente para Barros, que entiende la tesis de Hobbes y Bodino como una que reclama la soberanía para una persona o grupo de personas. Quizás por esto Barros cree que los tegímenes "autocráticos", en que la autoridad final parece ser una persona o grupo de personas, y no un hecho institucional constituido por reglas, presentan un problema especial desde el punto de vista de la limitabilidad jurídica de la soberanía. Pero esto es un error: cualquier problema de jlimitabilidad que exista en un régimen "autocrático" existitá en un régimen "democrático". Lo que es problemático no es el poder no democrático sino el poder no constituido, es decir, el poder constituyente.

La cuestión es evidente si volvemos a Hart. Si el "soberano" es un hecho institucional él puede ser perfectamente limitado, y esas limitaciones en realidad no son normas que le impongan deberes sino normas que especifican bajo qué condiciones se podrá y bajo qué condiciones no se podrá imputat una voluntad a ese "soberano". Usando la terminología de W N Hohfeld ${ }^{62}$, esas limitaciones no son deberes sino incompetencias: "Límites' no significa aquí la presencia de un deber sino la ausencia de potestad jurídica"63. Pero eso supone que el "soberano" es un hecho institucional, constituido por el derecho. Cuando el conflicto político impugna esa identificación institucional del soberano (como el 11 de septiembre, o en lo que Ackerman llama "momentos constitucionales" sobre los que volveremos hacia el final de este artículo), lo que aparece es un soberano pre-institucional que no tiene las competencias que las reglas constitutivas le reconocen, sino que se las artoga, en principio, todas.

Ésta y otras cuestiones planteadas por la distinción entre tiranía y dictadura han de quedar pendientes por el momento. Por ahora lo que me interesa mostrar es que la elección entre ambas no es una cuestión que pueda ser decidida por los hechos brutos ocurridos después de 1973, sino son parte de una interpretación política de esos hechos. En parte, esa interpretación es guiada por el modo en que hoy nosotros entendemos la constitución y reconstitución de la comunidad política chilena. En una buena medida, entonces, es una pregunta sobre cómo nos hemos de comprender a nosotros.

La pregunta que se nos plantea ahora se planteó también al interior del tégimen militar (lo que no quiere decir que su respuesta nos vincule en el sentido de que por ser la de él sea la correcta). En efecto, en la propia auto-comprensión del régimen la tensión entre dictadura y tiranía se mantendría abierta prácticamente hasta la hora final del mismo ${ }^{64}$.

61 Hart, Concepio de Derecho, 93.

62 Hohfeld, Conceptos Jurídicos.

63 Hart, Concepto de Derecho, 86.

64 Hay un sentido en que este artículo habla de lo que no se puede hablar, y ello se hará cada vez más notorio. En particular, no hay una palabra para designar a lo que en el texto ptincipal he denominado "régimen" de la junta militar que no implique responder el problema de la dictadura y la tiranía. Una tiranía no es ni puede ser un "régimen" o un "gobierno" o un "orden" etc. 
El régimen se auto-comprende como tiranía cuando entiende que la suya es una voluntad no sometida a reglas, es decir, una voluntad que se niega a constituit por la vía de negar las potencialidades no actualizadas. Esta idea ya aparece en el decreto ley $\mathrm{N}^{\circ} 1$ (18 de septiembre de 1973), como hemos visto, en el que la junta de gobierno anuncia que respetará la constitución y las leyes si le parece adecuado respetarlas. Luego se hace más explícita. En efecto, el decreto ley 128 (de 16 de noviembre de 1973), anuncia que "el poder constituyente y el poder legislativo son ejercidos por la junta de gobierno mediante decretos leyes con la firma de todos sus miembros y, cuando lo estimen conveniente, de los ministros respectivos" (art. 3). El rasgo central de la tiranía (que la fuerza de que el tirano dispone no está sujeta a ninguna limitación que no sea la voluntad del tirano, que es una fuerza que se niega a dejar de ser potencia y convertirse en acto constitutivo negando así las potencialidades no actualizadas) se afirma retrospectivamente de modo explícito en el artículo 1 del decreto ley 788 , que declara formalmente que el poder de la junta no ha reconocido límites: declárase que los decretos leyes dictados hasta la fecha por la junta de gobierno, en cuanto sean contrarios o se opongan, o sean distintos, a algún precepto de la Constitución Política del Estado, han tenido y tienen la calidad de notmas modificatorias, ya sea de carácter expreso o tácito, parcial o total, del correspondiente precepto de dicha constitución.

Hasta ahora, en otras palabras, el régimen ha sido, conforme al decreto ley 788 , una tiranía: fuerza no sujeta a reglas (la idea de seguir una tegla supone conceptualmente que la regla puede ser infringida, lo que es estrictamente imposible si la acción contraria a la regla la redefine: "ningún curso de acción puede ser determinado por una regla, si todos los cursos de acción se conforman a la regla", como sostuvo Ludwig Wittgenstein ${ }^{65}$ ). Pero el artículo 3 del mismo decreto ley parece anunciar una limitación del poder de la junta de gobierno:Los decretos leyes que se dicten en el futuro y que puedan ser contrarios, u oponerse, o ser distintos, en forma expresa o tácita, total o parcial, a alguna norma de la Constitución Política del Estado, tendrán el efecto de modificarla en lo pertinente sólo si de manera explícita se señala que la Junta de Gobierno lo dicta en el ejercicio de la Potestad constituyente.

El significado del artículo 3 parece ser que el tiempo de la tiranía se ha terminado y que comienza el de la dictadura: ahora es al menos posible que la acción de la junta de gobierno esté sujeta a reglas, aunque sean reglas que ella misma se ha dado, porque es posible que sus actos infrinjan una regla sin por eso redefinirla. Pero las cosas no resultan tan claras. Consideraremos a continuación sólo tres momentos, que cubren todo el período que sigue a la dictación del decreto ley 788 , en que esta opacidad se hizo aparente.

El 13 de septiembre de 1976 se dictó el decreto ley 1551, que con el nombre de "acta constitucional No 2" pretendió fijar las "bases esenciales de la institucionalidad". El artículo 2 transitorio de este decreto ley dispuso que "Dentro del plazo de un año contado desde la vigencia de esta Acta, los decretos leyes que hayan modificado la Constitución Política de la República en lo telativo a los Poderes del Estado y su ejercicio, deberán revestir la forma de Acta Constitucional".

Pero el 23 de agosto de 1977 la junta de gobierno, ante la imposibilidad de dar forma de acta constitucional a esos decretos leyes, y "en el ejercicio del Poder Constituyente", dictó el decreto ley 1873, que dispuso que: "En el artículo segundo transitorio del Acta Constitucional N², elimínase la

Llamarlo "régimen" en consecuencia, es tendencioso, pero no hay un lenguaje no tendencioso, es decir uno que (como mi uso anterior de "interrupción" del derecho) sea agnóstico entre dictadura y tiranía. Eso de lo que se debe preguntar si era una dictadura o tiranía no puede ser nombrado (chay aquí una conexión con la idea, propia del Antiguo Testamento, de que Dios no puede ser nombrado?). No deseo trivializat el problema ofreciendo una solución arbitratia (como inventar un nombre como "dictrania") o puramente formal (como " $\mathrm{X}$ " o "Y"). Prefieto continuar asumiendo que nuestro lenguaje político es en el sentido indicado tendencioso, y manteniendo eso presente.

65 Wittgenstein, Pbilosopbical Investigations, \$201. 
frase "Dentro del plazo de un año contado desde la vigencia de esta Acta", y sustitúyese la letra "l" minúscula del artículo "los" que sigue a la frase eliminada, por la letra "L" mayúscula"

Hecha esta modificación, lo que en el decreto ley 1551 era una limitación a la voluntad de la junta (lo querido por ella carecía de validez si no adoptaba la forma de un acta constitucional) demostró no serlo: la infracción a lo dispuesto por la regla redefine la regla.

El segundo ejemplo es el de las disposiciones transitotias del decreto ley 3465 ("aprueba nueva constitución política y la somete a ratificación por plebiscito"), dictado el 11 de agosto de 1980. Si el articulado petmanente de la constitución era el producto del régimen que se auto-comprendía como dictadura soberana, el articulado transitorio era el producto de la auto-comprensión del régimen como tirania, a la que la constitución no obligaba: cualquier disposición constitucional contraria a las reglas contenidas en las disposiciones transitorias $13^{a}$ y siguientes era inválida durante el período que comenzaba el 11 de marzo de 1980 (disposición 21² transitoria). Ahora bien, los poderes especiales que la constitución entregaba (nominativamente: véase la disposición $14^{\mathrm{a}}$ transitoria) a Pinochet contradecían lo que de acuerdo al capítulo inicial del texto permanente de la constitución eran las "bases de la institucionalidad" (vid. disposición $24^{2}$ transitoria). La tensión entre el articulado permanente de la constitución y su articulado transitorio es la tensión todavía no resuelta entre tiranía y dictadura, y que se mantendría latente hasta el 5 de octubre de 1988.

Ese fue el momento en que la definición entre tiranía y dictadura no pudo seguir postergándose. Pero incluso durante ese día es posible discernir el esfuerzo por posponer la decisión. A las 19:30, el denominado "subsectetatio del interior" de la época comunicó al país que, computadas 79 mesas, con un total del $0,36 \%$ del total, el voto por "Si" triunfaba por una diferencia de 17 puntos. La entrega de ese cómputo dejaba todavía abierta la posibilidad de desconocer el resultado del plebiscito y ocupar militarmente la ciudad de Santiago. La cuestión sólo se decidiría en la reunión que comenzó en el bunker de La Moneda a las 1:00 de la madrugada del 6 de octubre. En eșa reunión, a la que concurrieron los miembros de la junta militar y Augusto Pinochet, éste, según la crónica más autorizada, pidió a la junta una Ermächtigungsgesetz como la que obtuvo Hitler en 1933, es decir, un decreto de poderes extraordinarios. El requerimiento suponía negar que el ptoceso "constituyente" de la "dictadura" había sido capaz de constituir, que todas las opciones (incluido el recurso a la fuerza) estaban tan abiertas como el 11 de septiembre. Según la misma crónica, los miembros de la junta de gobierno entendieron que efectivamente las posibilidades no actualizadas habían sido negadas, y se negaron a su vez a concurrir a la dictación de ese decreto de poderes especiales. Cuando ellos se retiraron y quedó Pinochet solo en la habitación con el vicecomandante del Ejército, éste dijo a Pinochet: "Mi general, su Ejército está listo. Para lo que usted necesite". Pinochet "lo miró y guardó silencio por un segundo". Ese era el momento de la decisión final. La decisión ya no podía seguir posponiéndose, como se había hecho al modificar el artículo 2 transitotio del decreto ley 1873, o al dictar la constitución de 1980 y complementarla con las disposiciones transitorias, o incluso como lo había hecho el "subsecretario del interior" unas horas antes al dar como ganador parcial a la opción "si". Aceptar la invitación tácita del general Sinclair era decidir que la auto-comprensión final del régimen sería como tiranía. "La constitución se cumple, señor vice-comandante" respondió Pinochet ${ }^{66}$.

Nada de lo anterior implica sostener que la transformación de tiranía a dictadura operó esa madrugada "como el rayo que rasga el seno de la nube", instantáneamente. Ya hemos visto que las ideas de los agentes sobre lo que están haciendo no son el criterio definitivo de asignación de significado politico a los hechos realizados. Quizás Pinochet pensaba que la suya era una tiranía, que todas esas reglas que había dictado eran reglas que lo obligaban a hacer lo que su voluntad quería después de todo, y que si en algún momento ellas la limitaban, ellas serían modificadas, como el decreto ley 1551.

66 Cavallo et al., La Historia Oculta, 821. 
Quizás pese a lo que Pinochet creía el régimen ya había negado las posibilidades no actualizadas y por eso para el resultó ser fácticamente imposible negar el resultado del plebiscito. Las consideraciones anteriores no optan por ninguna de estas respuestas. Estas proposiciones no deciden la cuestión de si el régimen de Pinochet era una dictadura o una tiranía, porque ésta es una cuestión política que en consecuencia no depende de los hechos del caso sino de nuestra comprensión del orden posterior a 1990: ¿es un orden constituido por la dictadura soberana, o re-constituido después de 17 años de tiranía?

Estas últimas consideraciones nos han de llevar a dirigir nuestra atención hacia este proceso, paralelo al anterior, de actualización de la potencia constitutiva, es decir, hacia los indicios que manifiestan la auto-comprensión del régimen como dictadura. Los primeros parecen vislumbrarse con la creación de la Comisión de Estudios de la Nueva Constitución ${ }^{67}$, para continuat con la dictación de las actas constitucionales ${ }^{68}$ y culminar con la promulgación del (articulado permanente del) decreto ley 3464, de 8 de agosto de 1980, que promulgaba la denominada "constitución política de la república de Chile".

Cuando nuestra atención se dirige a la comprensión del régimen de la junta como una dictadura, se plantean nuevas cuestiones. Una de ellas es: ¿quién detenta el poder soberano que a partir de 1973 comienza a desenvolverse? Cristi afirma, sobre la base de las normas jurídicas dictadas por los militares golpistas, que la respuesta a ambas preguntas es "la junta de gobierno". Pero ya hemos visto que esta respuesta, en la forma que le da Cristi, es inaceptable. Ya hemos visto que no es suficiente para decir que la junta de gobierno tenía el poder constituyente notar que ésta se declaró superior a, la medida de, la constitución de 1925. Cristi está en lo correcto al notar que "lo que mide es superior a lo medido"69, pero no nota que no hay, no puede haber algo constituyente sin algo constituido, y que no puede haber algo constituido en la medida en que todas las posibilidades quedan siempre abiertas (Wittgenstein). Cristi no es capaz de integrar a su análisis el hecho de que la cuestión de si el régimen militar podía constituir (=podía negar su potencia, actualizándola) no es una cuestión conceptual o jurídica sino política. Por eso lo que los agentes creían que estaban haciendo no tiene ninguna prioridad epistémica o política sobre el significado de lo que estaban haciendo: esos actos son intentos de imponer la comprensión del régimen como dictadura o tiranía, y por ellos mismos entonces no nos dan pistas sobre cuál de esas comprensiones es la correcta. Ello porque es perfectamente posible que los militares golpistas hayan estado equivocados respecto de la significación constitucional del golpe: aquí que ellos hayan estado equivocados no quiere decir que describieron incorrectamente una realidad que era independiente de sus acciones, sino que fracasaron políticamente, fracasaton en imponer el significado que ellos reclamaron a las acciones que realizaron. El hecho de que ellos mismos hayan declarado, en el decreto ley 1, que respetarían la constitución en la medida de lo posible solamente no constituye prueba irrefutable de que hayan efectivamente asumido el poder constituyente. Cristi parece entender que la pregunta que nos ocupa ahora se responde por referencia a hechos, hechos cotmo qué disponía el bando $N^{\circ} 5$ o el decreto ley $27^{70}$, quién dio la orden de bombardcar La Moneda, etc. En ningún momento Cristi asume que el tipo de respuesta que esas preguntas demandan es completamente distinto. Esas preguntas son interpretativas, en el sentido de Ronald Dworkin ${ }^{71}$. La identificación de la actuación del poder constituyente es siempre y necesariamente ex post facto, y está siempre

67 DS (justicia) No 1064 , de 12 de noviembre de 1973.

68 Decreto ley 1319 ("crea el consejo de estado"), de 9 de eneto de 1976; decreto ley 1551 ("bases esenciales de la institucionalidad"); decreto ley 1552 ("de los derechos y deberes constitucionales"), y decteto ley 1553 ("regímenes de emergencia"), los tres últimos de 13 de septiembre de 1976.

69 Cristi, Jaime Gurnnán, 83.

70 El bando $N^{\circ} 5$ declaraba la "ilegitimidad flagtante" del gobienno de Allende y asumía el poder "por el solo lapso que las circunstancias lo exijan" (No 13); el decreto ley 27 (de 24 de septiembre de 1973) disolvió el Congreso Nacional.

71 Dworkin, Law's Empire, 65-73. 
Ninguno tiene poder suficiente para no temer la agresión del otro. Y en esta situación de igualdad natural el temor y la guerra, la violencia, son inevitables: cuando un invasor no tiene que temer más que el poder solitario de otro hombre, si uno planta, siembra o posee una morada conveniente, puede probablemente esperarse que otros vendrán con sus fuerzas unidas para desposeerlo y deprivarlo, no sólo de los frutos de su trabajo, sino también de su liberta y su vida. Y el invasor corre también el mismo peligro a manos de otros ${ }^{76}$.

Esta es la razón por la cual "es evidente que mientras los hombres vivan sin un poder común que los impresione a todos, estarán en esa condición que se denomina guerra; y que esa guerra es una guerra de cada hombre contra cada hombre".

Lo que Hobbes llama "el poder solitario de cada hombre" ("another man's single power") no es poder en el sentido de Arendt. Lo que caracteriza la condición natural de la humanidad de Hobbes es precisamente la ausencia de poder en este sentido, de "capacidad de actuar en concierto". Por consiguiente, la guerra de todos contra todos sólo puede terminar cuando los hombres desarrollan esa capacidad, constituyendo un poder mayor que el de cada uno de ellos. Ese poder es la suma de sus poderes individuales (en la imagen de la portada original del libro de Hobbes el Leviathan es un gigante cuyo cuerpo está formado por una multitud de hombres). La creación de ese poder es la constitución de la comunidad política y la soberanía:

La única manera de crear ese poder común, que pueda defenderlos de la invasión de los extraños, y del ataque de los otros, y así protegerlos de modo que cada uno pueda vivir y progresar de acuerdo a su propio trabajo y los frutos de la tierra, es conferir todo su poder y fuerza a un hombre, o asamblea de hombres, que pueda entonces reducir todas sus voluntades, por plutalidad de voces, a una voluntad: lo que quiere decir nombrar a un hombre, o asamblea de hombres, para que sea su persona; y que cada uno se reconozca a sí mismo como el actor de cualquier cosa que el que lleve su persona haga, o disponga que se haga, respecto de las cosas que se relacionan con la paz y seguridad comunes. Y que en consecuencia sometan sus voluntades cada uno a su voluntad, y sus juicios a su juicio. Esto es más que consentimiento o acuerdo: es la unidad real de todos en una persona, de modo que cada hombre puede decir a cada hombre: yo autorizo y renuncio a mi derecho a gobernarme a mí mismo en favor de este hombre, bajo la siguiente condición: que ustedes renuncien sus derechos en su favor, y autoricen todas sus acciones del mismo modo. Habiendo hecho esto, la multitud así unida se llama COMUNIDAD; en latín CIVTTAS. Es la generación de ese gran LEVIATHAN, o mejor dicho, para hablar más reverentemente, de ese dios mortal a quien debemos, bajo el Dios inmortal, nuestra defensa y paz [....] En esto consiste la esencia de la comunidad; que, para definirla, es: una persona, de cuyos actos una gran multitud, por acuerdos de unos con otros, se ha hecho cada uno de ellos el autor, para que use la fuerza y los medios de todos como lo crea conveniente para su paz y la defensa común ${ }^{77}$.

Al constituit el Leviathan, los hombres crean la comunidad política, la polis ${ }^{78}$. La constitución del poder tompe la simetría natural y con eso acaba la guerra de todos contra todos, la situación gobernada por la violencia. Hobbes es todo lo explícito que puede ser en cuanto a la manera en que este dios mortal es creado: como un hecho institucional, es decir, mediante un conjunto de reglas constitutivas que definen qué declaraciones de voluntad tienen, en adición a su significación "naturalística" (i.e. de ser la declaración de voluntad del ser humano que la formula) el status institucional de contar como las voluntad de todos. Pero no puede haber hecho institutional en condiciones de pura violencia. Por eso una situación gobernada por la violencia (fuerza) es una situación en que no hay

76 ibid.

77 ibid, cap. 17

78 Pot eso puede decitse que Hobbes inaugura el pensamiento político modemo al declatar que la comunidad política y el derecho son contingentes, no naturales. Fl tema es uno de los ejes del argumento de Atria, "I a ironía del positivismo jurídico". 
sujeta, en principio, a revisión, a la posibilidad de ser políticamente derrotada. Al ser interpretativas, las afirmaciones sobre la actuación del poder constituyente o la declaración de excepción son políticas en el sentido más estricto del término, porque tienen que ver con las preguntas políticas fundamentales como cuál es la comunidad política y cuál es el valor de mantener la lealtad a ella.

Por supuesto, lo anterior no implica que la interpretación política es cuestión de puta voluntad, que basta querer una interpretación para que ésta se haga correcta. Si en la noche del 6 de octubre la auto-comprensión del tégimen como tiranía hubiera sido victoriosa, entonces todo el proceso constitucional, cuyos inicios como hemos visto pueden rastrearse hasta noviembre de 1973, se habría reconstruido como un (auto-) engaño, y el régimen habría dado a entender que a su juicio el decreto ley 3465 en realidad no contenía una negación de la potencialidad de no-ser. Pero la opción de constituir pudo en definitiva más que la opción de mantenerse en el estado de potencia constante, y por eso tiene sentido discutir hoy la cuestión del significado constitucional del régimen de Pinochet.

\section{El poder y la violencia}

La distinción entre dictadura y tiranía es el correlato de la distinción entre poder y violencia (o fuerza), a la que debemos atender ahora. Poder y violencia (fuerza), entonces, son incompatibles como tiranía y dictadura. Muchas personas (veremos algunos casos más adelante) considerarán esta afirmación inaceptablemente ingenua; dirán, probablemente, que una comprensión "realista", es decir, no ingenua, de la relación entre poder y violencia reconoce a la segunda como el género y al primero como la especie: el poder como una especie de violencia. Esta es la idea que yace en algunas versiones de la caracterización del (poder del) Estado como "monopolio de la violencia (fuetza)".

Examinadas las cosas más detalladamente, sin embargo, la idea de monopolio de la violencia no es sólo una forma de violencia. En efecto, sólo puede haber monopolio de la violencia cuando hay algo en virtud de lo cual la violencia ha sido monopolizada, y eso no puede ser sólo más violencia. Lo que permite monopolizar la violencia es el poder, es decir "la capacidad no sólo de actuar sino de actuar en conjunto"72. El poder supone la existencia de relaciones de obediencia: Donde las órdenes ya no son obedecidas, los medios de la violencia no sirven; y la cuestión de esta obediencia no es decidida por la relación orden-obediencia sino por la opinión y, pot supuesto, por el número de aquellos que la comparten ${ }^{73}$.

La irreducibilidad del poder a la violencia es evidente si se considera el problema desde una perspectiva como la de Hobbes. Lo que caracteriza a la condición natural de la humanidad (en la que la vida es "solitaria, pobre, desagradable, bruta y breve"74) es precisamente la inexistencia de poder, que implica que es una condición gobernada por la fuerza. La solución, la forma en que es posible escapar de esa condición, es la creación de un dios mortal, un "poder común" en la forma del Leviathan. El relato de Hobbes es instructivo porque la razón por la cual la condición genetal de la humanidad se caracteriza por la guerra de todos contra todos es que en dicha condición no hay nadie que tenga poder suficiente para estar a salvo del ataque de los demás: La naturaleza ha hecho a los hombres tan iguales en sus facultades del cuerpo y la mente, que a pesat de que es posible encontrat un hombre manifiestamente más fuerte o más rápido mentalmente que otro, cuando se toma todo en cuenta las diferencias entre hombre y hombre no son lo suficientemente considerables como para que uno pueda reclamar para sí un beneficio que cualquier otro no pueda pretender también para é $1^{75}$.

\footnotetext{
72 Arendt, On Viabence, 44.

73 ibid, 49.

74 Hobbes, Leviathan, cap. 13.

75 ibid.
} 
poder, o el poder se ha disuelto o se está disolviendo: El poder y la violencia son opuestos; cuando uno gobierna absolutamente el otro está ausente. La violencia aparece donde el poder está en peligro, pero dejado a su propio curso termina en la desaparición del poder [....] Hablar de poder no-violento es en realidad redundante ${ }^{79}$.

Como ya está dicho, esta comprensión de las relaciones entre fuerza y poder es a veces recibida con escepticismo. Así, por ejemplo, Efrén Rivera cree que ésta es una concepción "benigna" del poder, la cual "lo trata como un fenómeno social unidimensional" 80 . Él considera que es preferible una caracterización compleja del poder, una que tome al poder como "un fenómeno que es al mismo tiempo productivo y represivo, benigno y dañoso, positivo y negativo" 81 . Esto no puede negarse, pero el dictum de Arendt no niega esta complejidad del poder. En particular, no niega que el poder pueda ser represivo. Desde un punto de vista hobbesiano, la finalidad precisa del poder es reprimir la acción de los hombres conforme a sus pasiones. Por eso puede decirse, sin negar lo anterior, que "el poder algunas veces recurre a la violencia o a la amenaza de la violencia" 82 . Lo que nos importa ahora, porque es central para entender el momento constitutivo del poder y la noción de poder constituyente, es que sólo la existencia de poder, incluso del poder que recurre a la violencia, hace a lo político posible. Esto nos conduce a lo que a nosotros nos interesa, que es la conexión entre el poder (el derecho) y la violencia en el momento constitutivo; la relación entre violencia y poder constituyente.

Para empezar, ¿es la conexión entre el derecho y la violencia en el momento constitutivo fundacional, contingente o de algún modo relacionada a su natutaleza constitutiva? Rivera sostiene que "muchos sistemas legales contemporáneos deben su existencia a procesos fundacionales marcados por la violencia"83. Él acepta que los sistemas jurídicos contemporáneos "no han sido engendrados sólo por la violencia" sino también por "cosmovisiones, ideales, aspiraciones, utopías" y cosas parecidas ${ }^{84}$. Esto ya es un reconocimiento a la tesis de Arendt, que por lo demás ya hemos comprobado en el caso chileno: la sola violencia puede destruir el derecho, pero no constituirlo. El carácter instantáneo de la destrucción no implica que la constitución sea igualmente instantánea (si necesitáramos comprobación adicional de esto basta mirar el caso de la posguerra iraquî. Pero Rivera tiene razón en que los tiempos fundacionales son tiempos violentos. Esto no significa que cada momento fundacional es un baño de sangre, sino que la fundación pacífica es la excepción más que la regla. Es esto lo que debemos intentar entender ahora.

\section{Violencia constitutiva}

Como el poder es "la habilidad no sólo de actuar sino de actuar en conjunto", no puede haber poder sin un agente colectivo. Pero ¿qué es lo que le da unidad a este agente colectivo? Hemos visto que Schmitt supone que la identidad del agente colectivo que detenta el poder es natural en el sentido de pre-política: la constitución, hemos visto que Schmitt dice, constituye la forma y modo de existencia de la unidad política, cuya existencia es anterior ${ }^{85}$. Aquí la unidad del agente político es dada preconstitucionalmente, de modo que lo que queda por organizar es su forma y modo de existir. La unidad del agente político estaría dada por datos etnográficos como la lengua común, un origen racial común, o algo así. Una comprensión de este tipo de la identidad política es el antecedente habitual de políticas de exclusión y exterminio racial, que ven en la diversidad cultural, tacial o étnica una amenaza

79 Arendt, On Violence. 59.

80 Véase Rivera, "Violencia y derecho", 5n.

81 ibid.

82 ibid.

83 ibid, 6 .

84 ibid.

85 vid. supra, el pasaje que acompaña la a. 32. 
a la identidad comunitaria. De hecho veremos más adelante que éste es lo que podríamos denominat la "fruta envenenada" dentro de la teoría constitucional de Schmitt, es decir, la parte que está internamente vinculada con su nazismo y que debe en consecuencia ser expurgada.

Para hacer esto, podemos comenzar notando que la tesis hobessiana es diversa. De acuerdo a Hobbes no hay agente colectivo en la condición natural de la humanidad, y la constitución de lo político es la constitución de un agente colectivo, un dios mortal, el Leviathan ${ }^{86}$. Pero esto nos deja enfrentados a una paradoja, a la paradoja central de la teotía constitucional ${ }^{87}$ : si la unidad de agencia colectiva es políticamente construida, entonces la primera decisión política es la afirmación de una voluntad existencial, de una voluntad de ser. Pero la voluntad de ser es la voluntad de un agente colectivo que afirma su identidad en el acto mismo de declararse constituido. Esto parece imposible: uno normalmente espera que exista primero un agente y sólo entonces puede actuar.

Jed Rubenfeld, discutiendo la constitución del pueblo norteamericano, hace la analogía con el nacimiento ${ }^{88}$. Pero el nacimiento de una persona, como nota el propio Rubenfeld, es iluminadoramente distinto a la constitución de una polis, porque nacer no es algo que el que nace haga, sino algo que le sucede "con poca o sin intervención de su parte"89. Sólo una vez que a una persona le ha ocurrido eso (nacer) es posible que actúe. Pero el nacimiento de una unidad política es algo diferente, porque no es algo que le pase a esa comunidad, sino algo que ella hace: nos damos nacimiento a nosotros mismos. O, como las trece colonias dijeron en 1776, en su declaración tan hermosamente explícita: Nosotros el pueblo de los Estados Unidos sostenemos estas verdades como auto evidentes.

Pero por supuesto, al entender la frase "x sostiene $y$ " como una afirmación de la existencia e identidad de $\mathrm{x}$, tanto $\mathrm{x}$ como $\mathrm{y}$ se definen recíprocamente. Sostenemos estas verdades como auto evidentes, pero también: esas verdades definen quienes somos, es decir, los que creemos en ellas. Y nótese que las verdades que sostenemos son auto-evidentes, es decir, "nosotros" creemos en ellas no porque hayamos sido convencidos por argumentos, sino porque se presentan inmediatamente a nuestra razón. Esta última afirmación debe ser entendida en sentido político, no metafísico. Significa que con aquellos que las niegan, no es posible ningún argumento político; si su negativa amenaza nuestra existencia, serán entonces nuestros enemigos: "consideramos al resto de la humanidad Enemigos en la Guerra, en la Paz Amigos".

La constitución del poder, entonces, es un acto de afirmación existencial hecho por el mismo agente que se está constituyendo. Es como el Barón de Münchhaussen que se toma de sus tirantes y se levanta a sí mismo para salit del río. El momento constitutivo es violento porque sólo puede haber un 'nosotros' en la medida en que haya (i.e. en la medida en que declaremos que consideramos al resto de la humanidad) un "ellos".

¿Cuál será la reacción de ellos frente a este acto de autoafirmación existencial? Normalmente ellos nos considerarán políticamente inexistentes, en tanto incluidos en su "nosotros" (los colonos norteamericanos como súbditos de la corona británica, los vascos o los catalanes como miembros del pueblo español, los mapuches como parte del pueblo chileno). La fundación pacífica es más la excepción que la regla, porque la reacción normal para ellos será negar nuestra existencia política como diferente a la de ellos, e interpretar nuestra autoafirmación como traición o subversión. Dirigitán su justicia normal contra nuestros actos de auto-afirmación que calificarán de ilícitos. Así, la violencia

86 La afirmación de que el agente colectivo necesita ser constituióo y no está determirado por datos étnicos pre-políticos resiste a su vez dos interprctaciones, que dan origen a visiones liberales y socialistas de la comunidad política. Éste es el punto donde Hobbes debe ser abandonado. Pero no habiendo llegado a ese punto, podemos todavia seguirlo (véase Atria, "¿Existen derechos sociales?").

$87 \mathrm{No}$, por lo ya visto, del derecho constitucional, para el que no sólo no es paradoja, sino no es problema.

88 Rubenfeld, Freedom and Time, 83

89 ibid. 
para ellos será normal: poder constituido, mientras que para nosotros será sólo fuerza. Esto explica la peculiaridad de la violencia fundacional. En efecto, al contrario de lo que ocurre con la violencia normal, la violencia fundacional no puede ser sujetada al derecho, porque sujetarla al derecho es negar su carácter fundacional. Lo que para ellos es aplicación del derecho para nosotros es un acto de guerra. Entonces triunfaremos y nos declararemos constituidos (y seremos luchadores por la libertad, patriotas o revolucionarios) o fracasaremos (y seremos criminales o terroristas). Nótese que aquí "triunfar" o "fracasar" no se refiere al resultado de una batalla o incluso una guerra: triunfar es ser el origen de una comunidad política que se entiende a sí misma como fundada en nuestra gesta. Esto es el poder constituyente, el poder que afirma la aparición de una nueva voluntad. En este sentido el poder constituyente cuando opera, opera como el rayo que rasga el seno de las nubes, como ya hemos oído a Cristi decir citando a Donoso Cortés. Por eso no puede comprenderse la violencia fundacional, constitutiva o revolucionaria desde el derecho: para el derecho la violencia fundacional es siempre trivialmente criminal. Por eso el derecho constitucional (a diferencia de la teoría constitucional) no puede comprender el poder constituyente.

Esto también muestra el grueso ertor que comete Cristi al sostener que "persisten en el texto constitucional aprobado ciertas instituciones que no permiten la plena expresión del nuevo sujeto del poder constituyente" 90 . La creencia de que lo constituido puede impedir la expresión de lo constituyente es en el mejor de los casos una mistificación incomprensible, y en el peor la ingenuidad irresponsable (muy común, por desgracia, en Latinoamética) del jurista que cree que para evitar el terror y la tortuta basta declarar a ambos contrarios a derecho y dar competencia a un juez para aplicar sanciones por esos actos.

Pero también hemos visto que del hecho de que el poder constituyente no reconozca, no pueda reconocer limitaciones jurídicas, en la medida en que es la fuente de la normatividad jurídica, no se sigue que pueda asumir cualquier forma. Aquí volvemos a la afirmación de Böckenförde: una voluntad absoluta, y que quiera seguir siendo absoluta, no puede constituir nada. El poder constituyente es una voluntad de constituir. Para constituir, debe negar las potencialidades no actualizadas.

Pero no se niega a sí misma por completo. Al actualizarse a sí mismo niega las potencialidades no actualizadas. Pero subsiste como una voluntad "además y por encima de la constitución" en la forma de la siempre abierta posibilidad de declarar lo excepcional, de suspender o destruir lo jurídico. Ya vimos que una teoría del derecho como la de Hart no tiene problemas en explicar las limitaciones jurídicas al "soberano" constituido, peto sólo en tanto constituido. La significación política del hecho de que la voluntad constituyente subsista "además y por encima" de la constitución es que el soberano constituyente no puede ser condicionado por el derecho, por cuanto al actuar el primero el segundo queda en suspenso. Se dice que Miguel Ángel decía que no era el creador de sus esculturas: siempre. habían estado ahí, y él sólo retiraba el mátmol sobrante. En el mismo sentido, el poder constituyente no crea lo constituido, sino se retira para que lo constituido pueda ser: remueve, podemos decir para continuar con la analogía, las posibilidades sobrantes. La idea de creación, en tealidad, es idólatra: Dios no crea al mundo, sino se retira para que el mundo pueda ser. Como el poder constituyente, Dios no crea, des-crea.

¿Y qué es lo que marca la irrupción del poder constituyente? Parte de la respuesta (pero sólo parte) es la interrupción del derecho, que es lograda por la fuerza. Si la normalidad, luego de ser desafiada por el intento de declarar la excepción, se reafirma a sí misma, entonces nada significativo ha sucedido porque tal intento será tratado como un crimen trivialmente normal (como el denominado "Tancazo", un intento de golpe que fracasaría en junio de 1973). Pero si la declaración es lo suficien-

90 supra, n. 25.

91 Schmitt, Teoria de la Constitución, 94. 
temente poderosa, interrumpe el sistema jurídico "in toto"92, como sucedió en Chile en 1973 (recuérdese: "intertumpe" es un término que pretende ser agnóstico entre el "suspende" de la dictadura y el "destruye" de la tiranía).

La otra parte de la respuesta es la que nos aleja de la idolatría: el ejercicio del poder constituyente no es reducible a la fuerza de la interrupción, debe ser capaz de des-crear, de constituir.

Dicho de otro modo: la excepción (lo constituyente) supone la normalidad (lo constituido). La declaración es un acto violento porque es jurídicamente contrario a derecho, y por eso - y en este sentido - no está sometida al derecho. Como la excepción suspende el derecho carece de sentido decir que su validez depende del contenido del derecho que suspende - otra cosa, por supuesto, es modificar el derecho para que la situación en que la excepción se declara too se presente: eso es lo que suele llamarse "estados de excepción constitucionales". Pero la excepción supone la normalidad en un sentido más radical, porque la excepción debe su carácter de tal a la manera en que ella es interpretada en la normalidad que sigue (si sigue).

La excepción, entonces, constituye la normalidad, pero la normalidad constituye la excepción al reconocerle su carácter constitutivo. Esto no es sino otra manifestación de la paradoja fundamental: lo constituyente constituye a lo constituido, pero es lo constituido, al entenderse como constituido, lo que hace constituyente a lo constituyente.

Negar esta paradoja lleva a uno de dos errores: uno es el del ingenuo que cree que la violencia excepcional puede ser enfrentada y controlada por el derecho como la violencia normal, como si el terror pudiera ser evitado declatándolo ilícito. El otro es el del cínico autodenominado "realista" que cree que la excepción ha de ser entendida en sus términos, que ella es reducible a la facticidad de la sola violencia.

\section{La excepción}

"Soberano es aquél que decide sobre el estado de excepción"93.

Con esta frase Carl Schmitt abre su pequeño tratado de teología política. Para entenderla, es útil volver sobre la noción de soberanía como ésta es discutida por Barros, que hace referencia a Hobbes y Bodino. Efectivamente, como dice Barros, Bodino enumera entre las "verdaderas señales de la suprema autoridad" la autoridad para "establecer normas con fuerza obligatoria general, declarar la guerra y hacer la paz, tesolver controversias y velar por el cumplimiento de las reglas, y elegir a los principales funcionarios del estado" ${ }^{94}$. De ahí Bartos colige que "su facultad clave radica en el poder para crear y derogar reglas"95, y esto implica que "el carácter definitivo ingerente a la soberanía hace estructuralmente imposible imponerle limitación legal alguna a la cúspide de la jerarquía legal["996. Ya hemos visto que esta forma de comprender la soberanía sufre de la incapacidad de distinguir límites materiales de límites "legales" (jurídicos). Es ptecisamente aquí donde la caracterización de Schmitt, que también la presenta como una lectura de Bodino, se demuestra más útil.

Porque, estrictamente, es falso que Bodino haya sostenido que el poder soberano se caracterizaba por ser jurídicamente ilimitado: Si dezimos que aquél tiene autoridad absoluta que no está sujeto a las leyes, no se hallará en el mundo príncipe alguno que sea supremo, visto que todos los príncipes de

\footnotetext{
92 Schmitt, Teología Política, 17. 93 ibid, 35.

94 Barros, La Junta Militar, 40, con referencia a Bodino, Las Seis Libros de la República. 95 Barros, La Junta Militar, 40.

96 ibid, 41.
} 
la tierra están sujetos a las leyes de Dios y a las naturales y a muchas leyes humanas comunes a todos los pueblos ${ }^{97}$.

¿Cómo hemos de entender esta calificación? Es importante destacar que no es una característica del soberano, o de su peculiar posición en la cúspide de la jerarquía jurídica, que en casos excepcionales las normas no lo obliguen, es decir, que las normas no se apliquen en casos suficientemente especiales $^{98}$. No se necesita ser soberano para no estar obligado por la promesa de visitar a un amigo si camino a su casa uno se encuentra con una persona accidentada y que requicre urgente traslado al hospital. Ese es un caso excepcional, en que el deber impuesto por la regla es derrotado. Lo característico del soberano es que tiene la autoridad final para declarar cuándo la pretensión normalizadora de las reglas es derrotada.

Precisamente porque no alega que lo característico del soberano es que carezca de obligaciones, que no sea obligado por el derecho, la tesis de Bodino no descansa, como lo hace la interpretación de Barros, en una insostenible distinción entre límites materiales y límites jurídicos. Es la decisión sobre la excepción lo que define al soberano: El mérito científico de Bodino, su éxito, se debe a haber insertado en el concepto de la soberanía la "decisión". Apenas se encuentra hoy un solo trabajo sobre el concepto de la soberanía que no registre las habituales citas de Bodino. Pero ninguno recoge aquel pasaje central de La República. Se pregunta Bodino si las promesas hechas por el príncipe al pueblo o los estamentos anulan su soberanía. Contesta, refiriéndose al caso que fuese necesario obrar contra tales promesas, modificar o derogar las leyes, "selon l'exigence des cas, des temps, des personnes". Si en tal sazón hubiese el príncipe de consultar previamente al senado o al pueblo, tendría que hacerse dispensar por sus súbditos. Solución que Bodino califica de absurda ${ }^{99}$. derecho.

Soberano es, entonces, aquél que decide sobre el estado de excepción, sobre la suspensión del

En esta sección pretendo defender una determinada interpretación de esta idea. Como en general con la manera en que creo que es útil recurrir a las ideas de Schmitt (y no sólo de Schmitt) no pretendo ofrecer una interpretación que desentrañe lo que él quería decir o tenía en mente con lo que dijo, porque este artículo no pretende se una contribución a la literatura sobre Schmitt. Lo que me interesa es en qué sentido lo que Schmitt vio con una clatidad inusual puede iluminar el análisis de situaciones como las que estamos tratando de entender.

La decisión sobre el estado de excepción no es una decisión que admita de validez en términos anteriores a ella, por lo que no es una interpretación plausible de la afirmación inicial de la Teología Política sostener que ella implica que una decisión sobre el estado de excepción es válida sólo cuando la ha tomado el soberano. La frase, entonces, no es ambigua, como erradamente cree David Dyzenhaus, entre la pretensión de que el que de hecho decide sobre el estado de excepción es el soberano, y la pretensión de que el soberano, en vittud de su posición como soberano, es a quien le toca decidir sobre el estado de excepción ${ }^{100}$.

Dyzenhaus, sin embargo, apunta a algo que será importante para nosotros, y es que, como hemos visto, la identificación del soberano es siempre una interpretación política retrospectiva, y en ese sentido reconocer una decisión sobre la declaración de la excepción como una decisión de ese tipo (y no como un acto terrotista o un delito común) es idéntico en significado a reconocer el poder soberano de quien la realiza. También hemos visto, sin embargo, que identificar al que toma una decisión es también una cuestión que resulta de una interpretación política formulada desde la normalidad sobre-

97 Bodino, Los Seis Libros de la República, 1.8 (p 274).

98 Esto es lo que se denomina la "derrotabilidad" de Ias reglas, en particular de las jurídicas. Véase Atria, Lany and Logal Reasoning.

99 Schmitt, Teología Politica, 19

100 Dyzenhaus, Legality and Legitimag, 43. 
viniente: ¿fue Pinochet, el ejército, las fuerzas armadas, la derecha o el pueblo chileno el que decidió suspender o destruir el derecho en 1973?

Sea quien sea quien tenga poder para decidir sobre el estado de excepción, entonces, es el soberano. Lo crucial tespecto del estado de excepción es que no es un puro estado de disolución del poder, de pura violencia. Si fuera una situación gobernada por la fuerza sería eso: caos, y no excepción. El estado de excepción es estado de excepción porque hace excepción a la normalidad, de la cual surge y a la cual retorna.

La importancia de este punto no puede ser exagerada. Toda la reflexión sobre la excepción y el poder constituyente debe centratse en la relación entre excepción y normalidad, entre poder constituyente y poder constituido, entre particular y universal. Al perder de vista que excepción y normalidad se definen mutuamente, es común malinterpretar la concepción schmittiana de lo político, y entenderla como "una descripción apocalíptica de la política"101.

Para aclarar el sentido en que excepción y normalidad (particular y universal) se definen recíprocamente puede ser útil recordar el significado técnico-jurídico, ya obsoleto, de la palabra exceptio. En el derecho romano clásico, la excepción del demandado no negaba la validez del argumento del demandante. Una stipulatio obtenida con dolo, por ejemplo, era perfectamente válida, por cuanto los únicos requisitos para la validez de la stipulatio eran requisitos puramente formales. Pero si bien la stipulatio era válida, el demandado alegaba la existencia de un hecho ultetior, y no vinculado con la validez del contrato que justificaba la obligación objeto de la demanda, en virtud del cual el juez no debía acoger la acción del demandante (por ejemplo, que el acreedor demandante no había entregado la cosa por la cual él había estipulado pagar el dinero ahota demandado y por eso podía decirse que actuaba dolosamente). El hecho alegado por el demandado es un "hecho no jurídico (en el sentido de ser irrelevante para el ius civile) que el pretor, empero, considera digno de tutela"102. El demandado solicitaba al pretor, entonces, que tomara (capere) su caso desde el interior (ex) de la regla (es decir, de entre los casos a los cuales la regla se aplicaba) y rechazara la acción ${ }^{103}$. Como ha sostenido Alan Watson,

El sentido de una exceptio es precisamente que el demandado no está negando la validez del fundamento invocado por el demandante. Él sólo está reclamando que hay otro hecho que debe ser tomado en cuenta ${ }^{104}$.

La exceptio, entonces, se distingue de otras alegaciones del demandado porque acepta la existencia de la obligación que invoca el demandante. "Si el hecho es civilmente relevante y la intentio es in ius, no se requiere una excepción, porque tal hecho de todos modos produce sus efectos"105. Vemos

101 ibid, 51 .

102 Guzmán, Derecbo Privado Romano, vol i, p. 151.

103 Para la etimología de exceptio, véase ibid, 150.

104 Watson, The Evolution of Lan, 26.

105 Guzrnán, Derecho Privado Romano, n. 71. Para entender la lógica de la exceprio es necesario estar familiarizado con ciettas características básicas del procedimiento formulario romano. Quien deseaba iniciar una acción no recutría en primer lugar al juez, sino al pretor. El pretor le concedía al futuro demandante una fómula, elegida de un catálogo (el edicto). La fórmula nombraba al juez y le dirigía una instrucción condicional: si se dan ciertas condiciones de hecho, ha de condenatse al demandado; si no se dan, ha de absolvérsele. El antecedente de la condición se denominaba intentio, y correspondia al demandante probatlo; la parte que contenía la instrucción que había de seguirse en el caso de ser probados los hechos narrados en la intentio era la condemnatio. Es digno de ser notado el hecho de que el pretor, entonces, tenía poder para decidir cómo debía ser el derecho aplicado, aunque no podía cambiatio. Éste es el espacio en el que surgió la exceptio. El solo hecho de tenet el acreedor derecho no erá suficiente para que tuviera acción, porque debía poder utilizar alguna de las fótmulas del edicto. Las excepciones restringían las pretensiones válidas que podían ser ejercidas mediante las fómulas correspondientes. Eso daba a la exceptio una identidad propia (por eso la distinción entre excepciones y defensas hoy carece de sentido). En efecto, si la defensa que el demandado pretendia intentar era que los hechos alegados por el demandante cran falsos (por ejemplo, porque la estipulación que el demandado alegaba no había en realidad existido) el demandado no tequería, como explica Guzmán, solicitar al pretor la 
aquí la naturaleza paradójica de la exceptio: la excepción sólo vale (como excepción) en tanto no vale (para el ius civile); está incluida porque está excluida ${ }^{106}$.

La excepción de la que habla Schmitt comparte esta naturaleza paradójica, aunque en un nivel más categórico. Si la exceptio romana era la manifestación de un contraste entre dos pretensiones jurídicas (contraste que se explica por referencia a la tensión entre el derecho civil y el derecho honorario), la excepción de la que habla Schmitt es manifestación de la "relación límite entre lo que está dentro y lo que está fuera del derecho"107, y se explica por referencia a la tensión entre derecho y politica. Una tensión semejante proveyó del contexto adecuado para una exploración especialmente aguda de este problema.

El problema I de Temor y Temblor, de Søren Kierkegaard es: “¿existe una suspensión teleológica de lo ético?" ${ }^{108}$. Según Kierkegaard, sólo comprendiendo una noción como ésta es posible entender la historia de Abraham (Gen 22: 1-14): $22^{1} Y$ ACONTECIÓ después de estas cosas, que tentó Dios á Abraham, y le dijo: Abraham. Y él respondió: Heme aquí. ${ }^{2} \mathrm{Y}$ dijo: Toma ahora tu hijo, tú único, Isaac, á quien amas, y vete á tierra de Moriah, y ofrécelo allí en holocausto sobre uno de los montes que yo te diré. ${ }^{3} \mathrm{Y}$ Abraham se levantó muy de mañana, y enalbardó su asno, y tomó consigo dos mozos suyos, y á Isaac su hijo: y cortó leña para el holocausto, y levantose, y fue al lugat que Dios le dijo. ${ }^{4} \mathrm{Al}$ tercer día alzó Abraham sus ojos, y vio el lugar de lejos. ${ }^{5}$ Entonces dijo Abraham á sus mozos: Espetaos aquí con el asno, y yo y el muchacho iremos hasta allí, y adoraremos, y volveremos á vosotros. ${ }^{6} \mathrm{Y}$ tomó Abraham la leña del holocausto, y púsola sobre Isaac su hijo: y él tomó en su mano el fuego y el cuchillo; y fueron ambos juntos. ${ }^{7}$ Entonces habló Isaac á Abraham su padre, y dijo: Padre mío. Y él tespondió: Heme aquí, mi hijo. Y él dijo: He aquí el fuego y la leña; mas dónde está el cordero para el holocausto? ${ }^{8} \mathrm{Y}$ respondió Abraham: Dios se proveetá de cordero para el holocausto, hijo mío. E iban juntos. ${ }^{9} \mathrm{Y}$ como llegaron al lugar que Dios le había dicho, edificó allí Abraham un altar, y compuso la leña, y ató á Isaac su hijo, y púsole en el altar sobre la leña. ${ }^{10} \mathrm{Y}$ extendió Abraham su mano, y tomó el cuchillo, para degollar á su hijo. ${ }^{11}$ Entonces el ángel de Jehová le dio voces del cielo, y dijo: Abraham, Abraham. Y él respondió: Heme aquí. ${ }^{12} Y$ dijo: No extiendas tu mano sobre el muchacho, ni le hagas nada; que ya conozco que temes á Dios, pues que no me rehusaste tu hijo, tu único; ${ }^{13}$ Entonces alzó Abraham sus ojos, y miró, y he aquí un carnero á sus espaldas trabado en un zarzal por sus cuernos: $y$ fue Abraham, y tomó el carnero, y ofteciole en holocausto en lugar de su hijo. ${ }^{14} \mathrm{Y}$ llamó Abraham el nombre de aquel lugar, Jehová proveerá. Por tanto se dice hoy: En el monte de Jehová será provisto.

Kierkegaard (bajo el significativo pseudónimo de Johannes de Silentio) cree que la expresión ética para lo que Abraham hizo es asesinato; la expresión religiosa es sacrificio, pero precisamente en esta contradicción está la ansiedad [...] y sin esa ansiedad Abraham no sería quien es ${ }^{109}$.

El problema de Temor y Temblor, entonces, es cómo entender a Abraham; dicho de otro modo, si es posible entender a Abraham de un modo distinto al que expresaba Kant en La Contienda entre las Facultades:

Aun cuando Dios hablase de hecho con el hombre, éste no puede saber nunca a ciencia cierta que es Dios quien habla. Es absolutamente imposible que el hombre pueda captar a través de sus

introducción de una excepción, porque el demandante tendría que probar los hechos constitutivos de la intentio en todo caso (sobre las formulas y sus partes, véase Schulz, Derecho Romano Clásico, \$30; Guzmán, Derecbo Privado Romano, \$13). Sólo cuando el becho invocado por el demandado no era relevante desde el punto de vista del ius civile tenía sentido hablar de una exceptio (vid. ibid, 151s).

106 Sobre la importancia de este punto, tanto para una explicación de algunas cuestiones sobre la evolución del derecho romano, como para explicar algunas cuestiones generales sobre el derecho y el razonamiento jurídico, véase Atria, Law and Legal Reasoning, $150-160$.

107 Agamben, Homo Sacer, 23.

108 Kierkegaard, Fear and Trembling, 54ss.

109 ibid, 30. Sobre la importancia del sacrificio, véase Atria, "Reconciliation and reconstitution". 
sentidos al ser infinito y reconocerlo como tal, diferenciándolo de los seres sensibles. Sin embargo, si puede llegar a convencerse de que, en determinados casos, esa voz que cree escuchar no puede cotresponder a Dios; ya que, por muy majestuoso y sobrenatural que pueda parecetle el fenómeno en cuestión, si lo que se le ordena contraviene a la ley moral, habrá de tomarlo por un espejismo ${ }^{110}$.

El texto anterior tiene una nota referida precisamente al caso de Abraham: Abraham tendría que haber respondido a esa presunta voz de Dios: "que no debo asesinat a mi buen hijo, es algo bien seguro; pero de que tú, quien te me apareces, seas Dios, es algo de lo que no estoy nada seguro, ni tampoco puedo llegar a estarlo"111.

Kierkegaard no niega que si alguien, luego de haber escuchado un sermón sobre Abraham el domingo, volviera a su casa e hiciera con su hijo lo que Abraham estaba dispuesto hacer con Isaac "sería ejecutado o enviado a un manicomio"112. Kant sólo plantea el problema, de cómo es posible entender a Abraham como un héroe de la fe a pesar de que lo es porque estaba dispuesto a cometer un acto aparentemente criminal. La situación de Abraham es paradójica: [La fe] es la paradoja por la cual [Abraham] está en la cima, la paradoja que no puede ser explicada a nadie más, porque la paradoja es que él como individuo singular se pone a sí mismo en una relación absoluta con lo absoluto. ¿Está justificado? De nuevo, su justificación es paradójica, porque si lo está, entonces él está justificado no en virtud de ser algo universal sino en virtud de ser el individuo singular ${ }^{113}$.

Esta es la situación que Kierkegaard denominó la "suspensión teleológica de lo ético", una situación en que lo universal (lo ético) queda suspendido, porque el particular se relaciona directamente con lo absoluto. Por eso si está justificado ello no es consecuencia de que la situación en que se encuentra está prevista en una notma ética (universal). Esto es lo que permite a Kierkegaard diferenciar la situación de Abraham de la de lo que él designa como el "héroe trágico" como Agamenon, Jephtah o Brutus ${ }^{114}$. Éste se mantiene dentro de lo universal (ético) pero que se encuentra en una situación que es trágica porque lo universal (ético) exige que entregue lo que más ama por un bien superior (salvar la ciudad, la república, etc). La situación del héroe trágico, entonces, es una en la que éste tiene el deber de entregar lo que más ama, y por esto él "está todavía dentro de lo ético"115. Éticamente la situación de Agamenon, Jephtah o Brutus no presentaba complejidad alguna; lo que los convierte en héroes trágicos no es su especial habilidad para discernir en circunstancias difíciles su deber, sino el coraje que ellos muestran al vivir a su altura. Por eso "no habrá alma noble alguna en el mundo que no vierta lágrimas de compasión por su agonía, de admiración por su acto"116.

La situación de Abraham es enteramente diferente. En la medida en que Abraham se mantiene en lo ético, debe negarse a sacrificar a Isaac: "no hay expresión más alta para lo ético en la vida de Abraham que que el padre debe amar a su hijo"117. Lo universal en la historia, dice Kierkegaard, "está crípticamente presente, por así decitlo, en los hombros de Isaac, y debe gritar en la boca de Isaac: 'no hagas esto, estás destruyéndolo todo"'118.

110 Kant, La Contienda entre las Facultades, 43. Así, es Kant quien en definitiva expresa la condena de Abraham que, según Kietkegaard, Hegel debería haber formulado (cf. Kierkegaard, Fear and Trembling, 54s).

111 Kant, La Contienda entre las Fackltades, 43.

112 Kierkegaard, Fear and Trembling, 29.

113 ibid, 62 .

114 Agamenon ofreció a su hija Ifigenia a la diosa Artemisa con el objeto de ganar vientos favorables para la flota griega que navegaba hacia Troya; Jephtah debió sacrificar a su hija para cumplir un voto a Jehová (Jueces, 11: 30-39); Brutus asesinó a su padre adoptivo para salvar Roma de la dictadura.

115 Kierkegaatd, Fear and Trembling, 59.

116 ibid, 58 .

117 ibid, 59

118 ibid. 
Pero Abraham lo hace: lo hace porque Dios se lo exige como prueba de su fe. En este caso, es lo universal (ético) lo que constituye la tentación. Por eso "mientras el héroe trágico es grande por su virtud moral, Abraham es grande por su virtud puramente personal" 119 . Si no es un asesino, Abraham es grande no por haber actuado éticamente, sino por haber resistido la tentación de actuar éticamente.

Al subir el Monte Sinaí, entonces, Abraham está, como individuo singular, en relación directa, inmediata, con lo absoluto; lo universal (ético) está suspendido. Su situación es una que no puede ser mediada: no puede hablar, porque cualquier cosa que diga expresará lo universal (esto es lo que Kierkegaard nos dice de Silentio). Para los observadores, la situación es completamente incomprensible ${ }^{120}$, porque los observadores miran desde lo universal. Pero o lo universal está (teleológicamente) suspendido, o Abraham está perdido.

¿Y qué hay del argumento de Kant? ¿Qué si Abraham estaba equivocado? La visión del cínico, que Kierkegaard imputa a un grupo que designa colectivamente como los "profesores" (docenter) es que lo que muestra que Abraham no se equivocó es que fue exitoso, que no perdió a Isaac y se convirtió en el padre del pueblo elegido. Los docenter pueden juzgar la excepción (y Abraham) sin comprometerse, asilados en "su posición permanente y su futuro seguro en un estado bien organizado"121. Esto les lleva a analizar la excepción "con una mezcla de arrogancia y miseria", arrogancia porque creen que la objetividad que les da su perspectiva profesoral les permite juzgar la excepción de un modo cualitativamente distinto que los que la juzgan desde su compromiso teligioso o político, y miseria porque no entienden que el hecho de que puedan tener una posición permanente y un futuro seguro en un estado bien organizado se debe a que viven en una normalidad constituida por la excepción, de modo que están en la misma situación que el resto. La cuestión de si Abraham se equivocó no depende del resultado, porque el resultado depende de si hubo o no error: Si el que ha de actuar quiere juzgar por el resultado, nunca comenzará a actuar. Aunque el resultado puede dar felicidad al mundo entero no puede ayudar al héroe, porque él no sabría el resultado hasta que todo hubiera terminado, y no sería un héroe por eso sino por comenzar ${ }^{122}$.

Es difícil no notar la conexión entre esta observación de Kierkegaard y la tesis ya mencionada de Hannah Arendt sobre la impredecibilidad y contingencia de la acción humana. "Actuar" es iniciar algo nuevo, algo que no está contenido en el pasado. Eso, por supuesto, no implica que no podamos o incluso debamos preguntarnos si Abraham estaba o no equivocado. Kant, como hemos visto, creía que si Dios hablata realmente a los hombres, el hombre nunca podría saber que es Dios realmente quien habla. Pero como ha sostenido Gillian Rose, Kant aquí desconoce el hecho de que "en la historia original de la Biblia la voz de Dios es presupuesta desde la orden inicial de viajar al Monte Sinaí: el lenguaje de Dios es anterior al lenguaje de los hombres"123. La situación de Abraham era excepcional, porque él estaba en relación absoluta con lo absoluto. La relación es "absoluta" porque no puede ser mediada. Entonces el problema es para nosotros, no para Abraham. En efecto, Abraham estaba seguro (la palabra de Dios es previa a la palabra de los hombres), como nosotros no podemos estarlo, porque no podemos entendetlo: cuando una persona camina la ruta del héroe trágico hay muchos que pueden aconsejarlo, pero el que camina por el estrecho camino de la fe no tiene nadie que lo aconseje - nadie lo entiende ${ }^{124}$.

124 Kierkegaard, Fear and Trmbling, 67. 
Quizás por eso en la parábola del juicio final (Mt 25: 31-46), no sólo los condenados, sino también los justos son sorprendidos por el juicio de Jesús ${ }^{125}$.

Que el problema sea para nosotros y no para Abraham quiere decir que al preguntar si Abraham estaba equivocado no estamos intentando juzgarlo, sino entendernos a nosotros mismos a la luz de la acción de Abraham. La pregunta por la suspensión teleológica de lo ético es una pregunta sobre cómo hemos de entender la función constitutiva de nosotros que adquiere lo ético, y cómo desde allí podemos entender a Abraham. Es en este contexto en que hemos de entender las palabras de Kierkegaard que Carl Schmitt cita en el capítulo I de Teología Política ${ }^{126:}$

La excepción surge en el seno de lo universal [... .] La relación es como sigue: la excepción piensa lo universal al pensarse a sí misma; desarrolla lo universal al desarrollarse a sí misma; explica lo universal al explicarse a sí misma. Así, la excepción explica lo universal y a sí misma, y si uno realmente quiere estudiar lo universal uno sólo necesita buscar una excepción legítima; ella revela todo de modo mucho más claro que el mismo universal. [Si las excepciones] no pueden ser explicadas, entonces lo universal tampoco puede ser explicado ${ }^{127}$.

Aquí es útil volver de Abraham al caso del 11 de septiembre de 1973. ¿Fue el bombardeo de La Moneda una acción que interrumpió el derecho, y en virtud de la cual la acción de la junta de gobierno dejó de estar mediada por el derecho? En la medida en que ella es mediada por el derecho, sus agentes son simples delincuentes comunes. Aquí la postura del docente que pretende juzgar manteniendo su prescindencia parece ser confirmada, porque pareciera que lo que impidió al derecho mediar la acción de los militares en ese día y los sucesivos fue el control que ellos mostraron tener de los medios de violencia (tanques, aviones, etc). Pero de esto no se sigue, como ya hemos notado, que la acción de la junta haya sido exitosa en suspender y no destruir el derecho. El control de los medios de violencia basta para interrumpir el derecho, no para re-constituirlo. La pregunta que nos ha ocupado aquí, la que enfatiza la distinción entre destrucción del derecho (tiranía) y suspensión del derecho (dictadura) es la pregunta que el docente no puede responder, porque es la pregunta de si hemos de entender que la fundación de nuestro sistema jurídico se encuentra en el 11 de septiembre y esa no es una pregunta sobre el 11 de septiembre sino sobre nuestro sistema jurídico, sobre nuestra comprensión de la comunidad política chilena.

\section{Escatología política}

Como ocurre con todos los conceptos políticos, el lenguaje más adecuado para explicar la relación entre lo constituyente y lo constituido es el lenguaje teológico: Es Dios quien por amor se retita de nosotros con el fin de que podamos amarle. Porque si estuviéramos expuestos a la irradiación directa de su amor sin la protección del espacio, del tiempo y de la materia, nos evaporatíamos como el agua al sol; no habría suficiente yo en nosotros como para abandonar el yo por amor. La necesidad es la pantalla puesta entre Dios y nosotros para que podamos ser. A nosotros nos corresponde atravesar esa pantalla para dejar de ser ${ }^{128}$.

125 Véase Segundo, La Historia Perdida, 217-221. Segundo muestra que la parábola del juicio final de Mt 25:31 es subversiva de la ley, de un modo paralelo a la parábola del buen samaritano.

126 Carl Schmitt cita estas palabras imputándoselas a "un teólogo protestante", sin indicación de su fuente: cf. Schmitt, Teología Politica, 27s. En otra parte Schmitt ha dicho de Kierkegaard que es "el único gtande entre [los románticos]" (Schmitt, Romanticismo Politico, 127 n. 16)

127 Kierkegaatd, Repetition, 226s.

128 Weil, La Gravedad y la Gracia, 81. 
Yo soy posible sólo en la medida en que Dios se retira; si Dios no se retirara no habría espacio para que yo existiera. Por eso, es incorrecto decir que Dios crea al mundo, Dios descrea al mundo porque Dios se retira para que el mundo pueda ser. Ésta es la primera idea.

Hay una manera idólatra, o infantil, de comprender a Dios como un ser todopoderoso cuyo atributo característico es que puede resucitar a los muertos o multiplicar los panes, etc: Es la imagen de Dios de de los que quieren un superego autoritario o creador celestial para adorar o en contra del cual rebelarse. Este Dios es también un mago-empresario, que economizó en materia prima creando el universo enteramente de la nada [...] sin nada que pueda decirse a su favor más que él es, después de todo, Dios ${ }^{129}$.

Esta comprensión idólatra de Dios, que conoce "la divinidad únicamente como poder"130, corresponde a la comprensión del poder constituyente como poder ilimitado. Para una comprensión no idólatra de Dios lo que lo caracteriza no es su poder sobrenatural. Del mismo modo, para una comprensión políticamente auto-consciente lo característico del poder constituyente no es su poder ilimitado. Es evidente que Dios tiene poder sobrenatural y que el poder constituyente no puede ser limitado por reglas constitutivas, pero es precisamente eso lo que muestra que la creación del mundo (o la constitución de la comunidad política) sólo es posible si Dios (o el poder constituyente) se retira, descrea. Esta capacidad de negarse, retirándose, es lo que caracteriza a Dios y al poder constituyente.

La segunda idea contenida en la idea de descreación de Simone Weil muestra la relevancia de la dimensión escatológica de la política: Dios se ama a sí mismo a través de nosotros: "así él, que nos da el ser, ama en nosotros el consentimiento para no ser"131. Esto puede parecer narcisismo (Dios se ama a sí mismo como Narciso amaba su propia imagen), pero sólo hasta que lo conectamos con la idea, hoy lamentablemente tan manida y gastada que ya no evoca en absoluto lo que realmente significa: la radical subversión de todas las formas humanas de sociabilidad, de que Dios es amor. Esta idea subvierte todas las relaciones humanas porque significa que la verdadera realización de la existencia humana es su negación. Pero nótese que esta afirmación: que la verdadera realización de la existencia humana es su negación, no sólo no es compatible con, sino estrictamente implica, algo así como el imperativo categórico de acuerdo al cual no debe tratarse a otros como medios, sino sólo como fines: negar la humanidad del otro, convirtiéndolo en un medio para mis fines, es opresivo, en la medida en que supone que la realización de mi existencia es la afirmación de mi individualidad. Negar la individualidad de uno ("no hay amor más grande del que da la vida por sus amigos") es realizar plenamente la propia humanidad ${ }^{132}$.

Esto nos permite una nueva vista de la idea escatológica en política, y así conectar la tesis defendida aquí con dos ideas tradicionalmente defendidas por la izquierda que parecen estar en contradicción con ella: el internacionalismo, que afirma la posibilidad (en principio al menos) de una comunidad universal, y la idea de la superación del derecho. Entender la importancia de la idea universalista y de la superación del derecho es particularmente importante, porque tradicionalmente esas dos ideas han

129 Eagleton, After Theory, 177.

130 Weil, Pensamientos Desordenados, 37.

131 Weil, La Gravedad y la Gracia, 81.

132 Por eso, como nota agudamente Juan Luis Segundo, hay una conexión interna entre tevolución y tesurrección. Véase Segundo, La Historia Perdida, 329n, quien cita el siguiente pasaje de Roger Garaudy: "Si soy revolucionario, esto significa que la vida tiene un sentido para todos. ¿Cómo podtía yo hablar de un proyecto global para la humanidad, de un sentido para la Historia, mientras que millares de millones de hombres en el pasado han sido excluidos de él, han vivido y han muerto [...] sin que su vida y su muerte hayan tenido un sentido? ¿Cómo podria yo proponer que otras existencias se sacrifiquen para que nazca esta nueva tealidad, si no creyera que esta realidad nueva las contiene a todos y las prolonga, o sea, que ellos viven y resucitan en ella? O mi ideal del socialismo futuro es una abstracción, que deja a los elegidos futuros una posible victoria hecha a base del aniquilamiento de las multitudes, o todo sucede como si mi acción se fundara sobre la fe en la resurrección de los muertos. Éste es el postulado implícito de toda acción revolucionaria y, más generalmente, de toda acción creadora". 
sido interpretadas de un modo perverso: la idea internacionalista llevó a negar la relevancia política (más allá de las necesidades estratégicas) de la comunidad, de la polis como sede de la acción política, y la idea de la superación del derecho explica en gran parte el desprecio que la izquierda tradicional tenía para el derecho y las instituciones políticas.

La buena noticia de la venida del Reino de Dios es la buena noticia de una comunidad humanizada, cuyo fundamento no esté en la violencia sino en el reconocimiento de la humanidad del otro'133. Es, para decirlo en los términos utilizados por Marx en la Crítica del Programa de Gotha, una comunidad en la que cada uno contribuye de acuerdo a sus capacidades y toma según sus necesidades, es decir, una forma de comunidad en que el bienestar de todos es parte del bienestar de cada uno. La relevancia de la dimensión escatológica (de las "utopias") es particularmente malentendida cuando se critica al pensamiento utópico el hecho de que la utopía sea difícilmente alcanzable y por eso sea putamente ilusoria o fantástica.

La idea de utopía, como ha argüido Peter Young siguiendo a Zigmunt Bauman, es tanto "un lugar que no existe" como "algo a ser deseado". La concentración en el primer sentido es lo que caractetiza al uso peyorativo de la noción de utopía: suele ser una efectiva manera de descalificar una idea decir de ésta que es "meramente utópica". Pero este uso ignota la segunda dimensión de sentido de la utopía, que enfatiza un elemento de esperanza: la esperanza de que las cosas serán distintas ${ }^{134}$. Lo que quiero mostrar ahora es que la idea de descreación de Weil, cuando es entendida en clave política, contiene esta segunda idea. Como dice Zenon Bankowski, utilizando la analogía de un viaje: Podemos decir que parte de nuestra utopía es construir el camino por el que debemos viajar. Y a medida en que hacemos esto, motivados por una esperanza que mira hacia el futuro [porque no tiene sentido comenzat a construir un camino si no tenemos una destinación - FAL], llegar al destino no tiene por qué ser nuestra finalidad principal, de modo que el proceso de construir el camino se hace tanto o más importante. El punto aquí es que la visión utópica es algo que mediante su orientación hacia el futuro opera en el presente. Así podemos decir que el significado del pensamiento escatológico de la iglesia temprana era que la visión del Reino era tan fuerte (era inminente) que transformaba la práctica de la iglesia; esto cambió luego cuando la esperanza era más débiili35.

No es posible entender ni la relevancia de la escatología ni la de las utopías en política, salvo como una forma de escapismo irresponsable, sin entender esta idea: es la esperanza (religiosa o política) de la redención o emancipación futura la que transforma nuestra práctica presente, de modo que la esperanza no es sólo una expectativa optimista: nosotros entendemos nuestra vida actual de modo distinto a la luz de la esperanza escatológica o utópica. Ahora bien, Dios se retira, dice Weil, para hacer posible el yo de modo que nosotros podamos renunciar a él y volver a Dios. ¿Para qué se tetira el poder constituyente? ¿Pata qué constituir? Creo que una buena manera de responder esta pregunta es atendiendo al problema de lo que se ha dado en llamar "derechos sociales", que son formas de identificar aquélla parte del bienestar de los demás que nos debe interesar políticamente. Una idea central para entender la relevancia de lo político (que sin embargo no ha sido defendida aquí ${ }^{130}$ ) es que sólo viviendo en comunidades constituidas podemos aptender a vivir como humanos. Como decía Marx, "si el hombre es moldeado por sus circunstancias, entonces es necesario hacer de esas circunstancias, circunstancias humanas"137. La primera condición para que esas circunstancias sean humanas es la constitución de lo político. Peto eso introduce una limitación al teconocimiento de la común humanidad de todos los hombres, porque implica asumir que tenemos obligaciones especiales con los miem-

133 Véase Atria, "Reconciliation and reconstitution". Véase también Segundo, La Historia Perdida, primera parte.

134 Young, "The importance of utopias in criminological thinking".

135 en Morton (ed), Beyand Fear: Vision, Hope and Generosity, 16s.

136 Marx and Engels, La Sagrada Familia, 6.3.d.

137 Algo he dicho al respecto en Atria: "Reconciliation as reconstitution". 
bros de la comunidad ${ }^{138}$. En este punto, es posible reaccionar de dos maneras: una es renunciar a lo que exceda lo que podemos hoy justificar sobre la base de obligaciones generales, y reconocer entre nosotros los mismos derechos que hoy nos resulta plausible atribuir a todos los seres humanos (con el mendigo que golpea mi puerta tengo el mismo deber que con el que sufte pobreza en otro continente - aquí mi deber con el segundo fija el estándar para determinar mi deber con el primero). La otra es reconocer entre nosotros deberes especiales, deberes que no debemos a otros miembros de la humanidad (tengo con el primeto - que es próximo (prójimo) - un deber especial que no tengo con el segundo). La diferencia es evidente en la justificación de los derechos sociales. El liberalismo justifica la asociación política sobre la base del mutuo desinterés racional de las partes en la posición original, y por consiguiente los deberes fundamentales de los ciudadanos entre ellos son los que corresponden a derechos "naturales", es decir, derechos que los individuos tienen en condiciones pre-políticas (ésta es la significación política, no metafísica, de la idea de derechos naturales ${ }^{139}$. Por supuesto, entendiendo así los derechos/deberes de los ciudadanos, la distinción entre ciudadano/no ciudadano es arbitraria, y es aceptada sólo por razones fácticas: Nuestro tipo ideal de liberal razonará de la siguiente manera. Si bien es moralmente obligatorio asegurar un piso de subsistencia a toda la humanidad, es (desafortunadamente) poco realista intentar redistribución transfronteriza a escala doméstica, no sólo por la escasez de recursos, sino también por la ubicación del poder soberano. Aunque esta restricción atenta contra el universalismo liberal, los derechos de bienestar estarán limitados a los connacionales ${ }^{140}$.

Nótese cómo Holmes asume la perspectiva de la común humanidad, de lo que nos debemos recíprocamente todos los seres humanos, y se niega a reconocer respecto del próximo (prójimo) un deber diverso del que reconoce con el lejano: en ambos casos es asegurar un piso de subsistencia. Es una cuestión puramente fáctica, carente de significación normativa (más que exculpatoria) el que no pueda cumplir mi deber respecto del lejano y sólo pueda hacerlo, entonces, respecto del próximo. El significado político de esta idea es que el vínculo especial, entre miembros de una misma comunidad política, no justifica derecho o deber alguno. Si hay derechos de bienestar, ellos no tienden a la igualdad, sino a asegurar un "piso de subsistencia". Crucialmente, lo que su perspectiva liberal impide a Holmes es que mi deber de atender al bienestar del otto es que su bienestar es mi bienestar. Como el liberalismo basa la justificación de la comunidad política en las condiciones que acordarían las partes en estado de naturaleza (es decir, sin suponer vínculo político alguno), no reconocerá más deberes que los mínimos, los que tienen por finalidad asegurar a todos un nivel de vida al menos ligeramente superior al estado de naturaleza para justificar así la obligación política.

Pero ¿no es la alternativa groseramente nacionalista? No es moralmente grosero - y políticamente obsceno - decir que tengo un deber especial con el prójimo sólo porque está cerca de mí, y que no tengo una obligación equivalente respecto del que sufre como él pero está lejos? ${ }^{141}$

Antes de responder esta pregunta, nótese el dilema ante el cual nos encontramos: o afirmamos que la proximidad es moral - o políticamente, que aquí es sinónimo - irrelevante, o no lo es. Si es irrelevante, debemos concluir que con el lejano tenemos los mismos deberes que con el próximo. Ahora bien, è es el deber de luchar contra la pobreza y la marginación, contra la desigualdad, igualmente intenso a escala local que a escala universal? Nuestras prácticas políticas suponen que no lo es. Pero ¿cómo explicar esto si la proximidad o lejanía del otro es política o moralmente irrelevante? ¿Es sólo etnocentrismo, o racismo?

138 En lo que se tefiete a la discusión específica de los detechos sociales, lo que sigue está desartollado más completamente en Atria, "Existen derechos sociales?".

139 Véase Holmes, "The liberal idea", 86-91, y Atria, "¿Existen derechos sociales?" 31s.

140 Holmes, "The libetal idea", 39s (el destacado es agtegado).

141 Boff, Jesucristo el Liberador, 66. 
La respuesta liberal de Hoimes, que hemos visto, pese a todo lo bienintencionada que es, supone definir el deber con el próximo de acuerdo al deber con el lejano: con ambos tenemos el deber de asegurar un piso de subsistencia. Todo lo demás es lo que el pensamiento libetal entiende como "supererogatorio". Nuestro dilema es: o la lucha por instituciones que busquen algo más que asegurar un piso de subsistencia todos es supererogatoria (es decir, no exigida por la justicia) o es racista (o etnocentrista, etc).

Quizás podamos entender el problema a partir del modo en que éste aparece en la historia de Jesús. Aquí nos encontramos con un discurso que anunciaba la venida del Reino. El Reino no debe ser entendido como una cuestión puramente espiritual, algo que no pertenece a este mundo. Al contratio, es "la verificación de una esperanza, al fin del mundo, de superación de todas las alienaciones humanas, de destrucción de todo mal físico o moral, del pecado, del odio, de la división, del dolor y de la muerte". Ahora bien, el Reino suponía una transformación de las conciencias (lo que en la tradición de izquierda se denominó el "hombre nuevo"), una radical transformación de todas las formas de socialización humanas, porque es una comunidad constituida por individuos que entienden que su plena realización es la negación de su individualidad, como hemos visto. Negar la individualidad propia significa entender que la realización de uno es la realización de todos, que el bienestar del otro es el bienestar propio.

En este punto Jesús se enfrentó al dilema en que estamos nosotros, que enfrenta también toda tradición revolucionaria: ¿qué ha de hacerse antes del triunfo de la revolución? ¿Es posible predicar el Reino, en que el bienestar de todos es el bienestar de cada uno, e ignorar el sufrimiento actual de los pobres, los enfermos, los marginados? Pero ¿qué en particular debe hacer el que predica el Reino cuando nota que su atender al sufrimiento actual de los pobres, enfermos o marginados produce más alienación? El dilema es: o atender al sufrimiento actual, mediante medidas "asistenciales", haciendo menos evidente el hecho de que el reino sólo vendrá si hay una conversión en los corazones, o ignorar el sufrimiento actual, enfatizando la necesidad del cambio en los corazones, cambio sin embargo que no se conecta con lo que él debe hacer ante el sufrimiento particular de un sujeto en frente suyo. Pot supuesto, éste es el dilema que la izquierda revolucionaria enfrentó a principios del siglo XX: ¿reforma o revolución? Si la revolución pretende acabar con la alienación del proletariado, ¿debe el revolucionatio luchar por introducir reformas al orden existente que, sin producir la revolución, disminuyan la pobreza y marginación? ¿Y qué si estas reformas hacen menos probable el éxito de la revolución? Pero ¿no es absurdo (o hipócrita) preocuparse de la alienación y marginación pero oponerse a medidas que la disminuyan? ¿Puede lucharse contra la alienación y el sufrimiento sin atender al que los sufre?

Este dilema permite entender la función de las curaciones milagrosas de Jesús, y dos características reiteradas de todas esas historias. El problema de las curaciones milagrosas es que ellas hagan creer a la multitud que las observa que Jesús es un taumaturgo, un mago que puede sanar, y que la predicación del Reino entonces no implica nada respecto de ellos, que serán objeto de la magia de Jesús. Por eso una preocupación constante, observable en cada caso en que Jesús hace curaciones milagrosas, es conectar el milagro con la necesidad de este cambio en las conciencias. Ese intento puede a veces parecer incluso irónico. En la curación del paralítico relatada por Marcos (2: 1-12), el paralítico, que no ha podido, a causa de la multitud, entrar en la casa donde estaba Jesús predicando, es descolgado en camilla por sus amigos que han practicado una abertura en la techumbre. Después de este aparatoso esfuerzo por acceder a Jesús para que le curara su parálisis, Jesús le dice "tus pecados te son perdonados", lo que genera una discusión entre con los escribas sobre el poder para perdonar los pecados. En el contexto de esta discusión Jesús sana al paralítico. Pero entonces, ¿Por qué comenzó burlándose, al parecer, de la imperiosa y tozuda necesidad de curación que hace atravesar tantos obstáculos? En realidad, no se burla. Interrumpe el proceso que lleva inmediatamente a la curación, para ensanchar el panorama y hacet pensar en un Reino donde la tarea de humanización pasa por todas las marginaciones: la posesión, la enfermedad, la pobreza, el título de "pecador".... Sólo que, aquí también, parecería 
que lo que se ve cierra el espacio de la reflexión. La magnitud de lo presente domina: "Jamás vimos cosas parecida" (Mc 2: 12) ${ }^{142}$.

Esta "interrupción", en la cual Jesús intenta, con éxito variable, poner el acto milagroso de curación en el contexto de la prédica del Reino, pretende evitar la reducción de su intervención a la taumaturgia. Previendo que ella no sería suficiente ("la magnitud de lo presente domina"), Jesús recurre a una suerte de "damage-limitation exercise" desesperado: pedir a los presentes y especialmente a los beneficiarios de las curaciones que guarden el secreto (así, por ejemplo, dice al leproso después de haberlo sanado en Mc 1: 44 y a Jairo después de haber resucitado a su hija en Mc 5: 43; a los que piden un prodigio para creer, se los niega en Mc 8: 12).

Resumiendo, Marcos muestra así a Jesús frente a la triste disyuntiva en que lo coloca la incontable legión de los pobres que necesitan su poder bienhechor, esté o no por venir reino alguno. ¿Cómo librarlos de la urgencia - desesperada, pero inmediatista y superficial - para anunciar con ellos algo que está por venir, que está en la misma línea de sus deseos, pero que va más lejos, mucho más lejos? ? $^{143}$

Ahora podemos volver al problema de nuestros deberes especiales para nuestros próximos. La preocupación por el próximo adquiere un sentido diferente al meramente asistencialista cuando su significado es la anticipación de una forma de comunidad en que el bienestar de todos es el bienestar de cada uno. En otras palabras: la preocupación por el próximo no niega el ideal de común humanidad, porque es la práctica política la que redefine qué es lo que nos debemos unos a otros. Nos preocupamos de los "próximos" (prójimos) como una manera de anticipar el momento en que podremos hacer próximos a toda la humanidad. En conclusión: "necesitamos constituir para aprender a llevar vidas humanas en circunstancias des-constituidas. El poder constituyente descrea para que a través de la práctica política que tal descreación permite nosotros aprendamos a negatla. Sólo la esperanza escatológica (utópica) permite distinguir la lucha política local de formas más o menos sofisticadas de racismo o etnocentrismo"144.

\section{El concepto de lo político}

Chantall Mouffe nos ha recordado que la palabra política tiene dos raíces, que pueden ser interesantes en este contexto ${ }^{145}$. La primera es, desde luego, polis, lo que enfatiza la unidad de agencia. El problema de la constitución de la polis es, como hemos visto, el problema de la constitución del

142 Segundo, La Fistoria Perdida, 260.

143 ibid, 264.

144 Hay aquí una cuestión que debe ser advertida. Lo dicho en el texto sobre la distinción entre la preocupación "asistencialista" con la miseria y la marginación y la preocupación que, informada por una visión escatológica (utópica) anticipa una forma humanizada de comunidad no es consecuencia inmediata de la visión escatológica (utópica), sino depende en parte del contenido de la utopia en cuestión. Por eso es importante, en el argumento de Juan Luis Segundo, no sólo que Jesús predicaba el Reino, sino también que el reino suponía una transformación de las conciencias. La visión escatológica (utópica) sólo puede tener esta dimensión, y servir entonces como auténtica utopía política y no como una forma infantil de escapismo, cuando la visión utópica es tal que puede proyectarse sobre el presente, dando a lo que hoy hacemos un sentido distinto, adicional (como anticipación de lo que está por venir). En el contexto de la crítica de lo que él denomina "el motivo obstétrico", conforme al cual la historia produce junto a cualquier necesidad social los medios para su solución, Gerald Cohen distingue el marxismo "evolucionario" del socialismo "utópico". Los defensores del primero "están preparados para trabajar por el cambio dentro del capitalismo porque ven ese cambio como parte de la auto-transformación del capitalismo en socialismo". Pero los socialistas utópicos "no tienen el concepto de la au to-transformación capitalista, por lo que ellos no pueden entender de este modo la reforma, y por eso a menudo no ven ningún valor en ella, o creen que es contraproducente" (Cohen, If You're Egalitarian, 71). Aquí la utopía cumple un rol precisamente opuesto al destacado en el argumento del texto principal, neutralizando toda acción que no es radicalmente revolucionaria. El descrédito de la idea utópica en política es imputable a estas formas particulares de utopía. 145 Véase Mouffe, El Retomo de lo Politico, 14. 
agente político, que es en sí mismo un acto político. Es a través de la acción política que afirmamos nuestra identidad como una comunidad política que se autogobierna ${ }^{146}$.

La segunda raíz, polemos, destaca la conflictividad de la acción política. Lo que es político en el sentido de polémico es que debemos actuar colectivamente, pese a que no estemos de acuerdo en qué curso de acción seguir. La necesidad de actuar colectivamente y el desacuerdo en torno a la acción a ser colectivamente emprendida configuran lo que Jeremy Waldron ha llamado las circunstancias de la política'147. El problema central de lo político en el primer sentido es la constitución del agente político, del "nosotros"; en el segundo sentido, lo político es la deliberación o el conflicto sobre la forma y modo de existir, de actuar, de ese nosotros. Correlativamente, el conflicto político tiene dos dimensiones: uno es el conflicto sobre lo que Schmitt llamaba "la forma y el modo" de existencia la comunidad política. Pero el conflicto político tiene también una dimensión reflexiva, porque alcanza también a la identidad misma de la comunidad política ${ }^{148}$. El argumento desarrollado más arriba pretende mostrar, a propósito del caso chileno post-1973, que cuando este aspecto es ignorado hay una completa dimensión de sentido de los hechos que queda excluida. Ahora quiero terminar este artículo mostrando que el derecho necesariamente excluye esta dimensión, y eso muestra que la política es irreducible al derecho.

Al referirme al principio de este artículo al hecho de que las teorías disponibles para explicar un proceso como el seguido por Chile a partir del 11 de septiembre de 1973 son seriamente deficitarias me refería a su incapacidad para asumir esta reflexividad del conflicto político. Por "teorías disponibles" me refería principalmente al liberalismo y lo que se ha denominado "republicanismo cívico".

El liberalismo reconoce la posibilidad del conflicto reflexivo, lo que Rawls llama "la profundidad absoluta de ese conflicto latente irreconciliable"149. El modo en que el liberalismo reacciona ante la potencial radicalidad del conflicto político es negándola. Para negarla excluye de "lo político" lo que ve como bases de conflicto, que desplaza a la esfera privada. Hay dos estrategias para logtar esta finalidad, y ellas definen dos formas de la teoría política liberal: una niega la autonomía de lo político y entiende el conflicto político como el paradigma del conflicto no reflexivo, es decir, el conflicto en el cual la identidad de los agentes nunca está en cuestión: el conflicto de mercado, entre partes que negocian para acordar los términos de su intercambio. La escuela denominada del public choice sigue esta estrategia. La otra versión, que es la preferida por Rawls, es la de buscar un consenso por superposición que excluya de la estructura básica de la sociedad todo lo que sea conflictivo (especialmente: las concepciones del bien de cada ciudadano). De este modo el momento excepcional para el liberalismo es extraño a lo político.

Lo que es común a ambas visiones, en lo que nos interesa aquí, es una determinada manera de concebir la relación entre el derecho y la política. El liberalismo comprende al derecho como externo a la política, ya como un conjunto de límites al proceso político que garantizan libertades lexicográficamente ordenadas respecto de otros bienes, ya como un conjunto de reglas que restringen las posibilidades negociadoras de las partes del proceso político, del mismo modo en que las reglas de orden público limitan las posibilidades negociadoras de las partes de un contrato. Esto hace que la teoría política liberal (en particular la norteamericana) tenga dificultades para integrar dentro de ella la idea democtática y la idea constitucionalista ${ }^{150}$. Como la teoría liberal ignora la dimensión constitutiva

$146 \mathrm{El}$ argumento de esta sección está fuertemente influido por Christodoulidis, Law and Reflexive Politics.

147 Waldron, Lay and Disagreement, 101ss.

148 vid. Christodoulidis, Law and Reflexive Politios.

149 Rawls, Political Liberalism, xxvi [20].

150 En su introducción a la edición en castellano de Ackerman, La Política del Diálogo Liberal, Gabriela Alonso afirma correctamente que "durante las últimas décadas, la 'dificultad contramayoritaria' ha fascinado a los teóticos constitucionales" (9). Alonso continúa explicando la manera en que esta "dificultad" es solucionada o disuelta por diversas teorías norteameticanas. 
de la constitución y la política, no puede sino ver la constitución como "la restricción del rango de opciones políticas abiertas a la mayoría actual"'151, es decir, un conjunto de normas que limita la libertad de lo constituido. Así las cosas, se enfrenta al "notorio problema de la naturaleza evidentemente anti-democrática del derecho constitucional"152 (el constitucionalismo europeo, por su parte, es más conciente de la dimensión constituyente de la constitución, y está en consecuencia mejor preparado para entender que la constitución no es sólo un conjunto de límites a lo constituido). En esta comprensión de la relación entre el derecho y la política no hay cabida para el momento excepcional, que desde luego es el momento en que las "restricciones" contenidas en la constitución, entendidas como tales, son superadas. El constitucionalismo liberal (norteamericano) entonces sólo puede entender a la excepción como extraña a la normalidad. En los términos indicados más arriba, no es cínico como el docente de Kierkegaard sino ingenuo, y por eso es constitutivamente incapaz de entender no sólo la excepción sino tampoco la normalidad. No ha aprendido a hacerlo ni en la escuela de derecho de Guantánamo.

La tradición cívico-republicana parece estar en mejor posición que el liberalismo para dar cuenta de la excepción, porque para el republicanismo la relación entre la constitución y lo político es interna, es decir, la constitución hace posible lo político: "el republicanismo es una teoría sobre cómo la soberanía política encuentra expresión en el derecho. El derecho, sostienen los republicanos, hace posible la soberanía popular facilitándole reglas constitucionales como el vehículo o el "hogar" de la deliberación política" 153 . De este modo el republicanismo pretende disolver la anomalía contramayoritaria, afirmando que la constitución vincula al pueblo como un todo, pero lo vincula como el lomo de un libro vincula a sus páginas. La constitución es lo que mantiene unida generación tras generación de atmericanos en un sujeto político único ${ }^{154}$

Lejos de restringir la libertad del pueblo para auto-gobernarse, la constitución hace posible que exista algo así como un agente político que actúa en el tiempo.

En precisamente esta línea, uno de los más destacados y sugerentes autores republicanos, Bruce Ackerman, ha intentado construir una teoría de la constitución norteamericana distinguiendo entre lo

151 Klarman, "Constitutional fact/constitutional fiction", 796.

152 Rubenfeld, Freedom and Time, 10 (cursivas agregadas). El libro de Rubenfeld es de una sofisticación y agudeza inusual en esta materia. Su tema central es precisamente que a través de la acción políica, extendida en el tiempo, es posible la constitución de un agente colectivo como el "pueblo norteamericano". Esto lo lleva a oponer el modelo del "constitucionalismo escrito" al del "constitucionalismo hablado". Es indicativo de un clima intelectual, sin embargo, que a pesar de toda su sofisticación y sensibilidad filosófica y política, cuando llega a la obsesión norteamericana con el judicial review el argumento se hace pueril. "La revisión judicial se sigue de las premisas del constitucionalismo escrito", nos informa (ibid, 169): "el constitucionalismo escrito no puede existir sin tevisión judicial" (ibid, 172). Esta es una afirmación sorprendente, y para ella Rubenfeld sólo ofrece el siguiente argumento: "referir cuestiones de interpretación constitucional a la mayoria haría a los ciudadanos del presente jueces en su propia causa. El resultado de eso sería hacer a los compromisos contenidos en la Constitución tan sólidos como las promesas de año nuevo [New Yeat resolutions]" (ibid). Uno de los puntos más notables del libro de Rubenfeld es que vincula no sólo la identidad del agente político a su desarrollo en el tiempo (al pasado futuro, como está dicho más arriba), sino también la identidad de la persona: "si la personalidad es intrinsecamente [...] extendida temporalmente, la pregunta entonces es: ¿cuánto tiempo toma ser una persona? Y si ser una persona significa vivir un cierto tipo de vida, una respuesta natural puede ser: toda una vida" (ibid, 137). Pero entonces para poder ser una persona debemos poder contemplar nuestra vida completa como viviendo un tipo de vida, lo que quiere decir asumir compromisos con ciertos modos de vivir y vivir conforme a ellos. Ahota bien, es posible que a veces no estemos segutos sobre qué es lo que esos compromisos nos exigen: cunimos a la resistencia o quedarnos para cuidar a nuestra madre enferma? en el famoso ejemplo de Sartre. Seguramente sería absurdo decir que para que esos compromisos fueran algo más que promesas de año nuevo es necesario que entreguemos a un tercero la potestad de decidirlos por nosotros. Por supuesto que seremos jueces de nuestra propia causa. El punto es, no hay nadie más que pueda entender lo que está en juego. La respuesta de Rubenfeld al problema de la tevisión judicial realmente desanda todo el notable camino que hasta entonces había recorrido en su libro.

153 Christodoulidis, Law and Reflexive Politics, 10.

154 Rubenfeld, Freedom and Time, 177. 
que parecería ser normalidad y excepción, entre "política normal" y "política constitucional"155. El gobierno normal, día a día, incluidas las decisiones de los órganos representativos, son momentos de "política normal". Durante esos momentos la política discurre de acuerdo a las decisiones tomadas por el pueblo en los momentos constitucionales del pasado. Pero la política normal puede ser interrumpida por "momentos constitucionales", en los que el pueblo deja oír su voz con la finalidad de modificar o cambiar esas decisiones constitutivas. En esos momentos constitucionales el pueblo puede usar no sólo el procedimiento de reforma constitucional del artículo $\mathrm{V}$ de la constitución norteamericana, sino también "formas institucionales extraordinarias" 156.

Esta posibilidad de utilizar "formas institucionales extraordinarias" parece acercarnos a la cuestión de la excepción. En términos estrictamente formales, la modificación de la constitución de acuerdo al procedimiento informal que los momentos constitucionales pueden asumir es inconstitucional. Pero eso, para Ackerman, no quiere decir que esas modificaciones violen la constitución. Aunque juzgados desde el punto de vista de la normalidad esas decisiones deberían ser ilegales, ellas tienen la suficiente entidad como para redefinir los estándares de legalidad y entonces afirmarse a sí mismas.

Pero en realidad la solución no es tan sencilla. Nótese, en primer lugar, que la idea de "formas institucionales extraordinarias" ("extraordinary institutional forms") es una contradicción en los términos: las instituciones son conjuntos de formas ordinarias, normales. Lo que la constitución normaliza es precisamente la imputabilidad al pueblo de una decisión: una decisión es reconocida como una decisión del pueblo (i.e. del sujeto del poder constituyente) cuando se ha manifestado de acuerdo al procedimiento de reforma constitucional.

Pero por supuesto, esto nos devuelve al problema original: si las instituciones (i.e. lo que Hart llamaba "reglas secundarias") son las que nos permiten imputar al pueblo una voluntad, ¿cómo es posible imputar al pueblo la voluntad constituyente, es decir la de constituir instituciones que permitan imputar voluntad al pueblo? Esto nos muestra algo importante: la voz del pueblo, en cuanto sujeto del poder constituyente, es siempre reclamada por quien de acuerdo a las reglas institucionales para identificar al pueblo no es sino una facción (lo militares chilenos o la derecha en 1973, etc). Ia importancia de este punto es evidente cuando volvemos a lo que Cristi dice sobre el decteto ley 1 que declaró que la constitución sería respetada "en la medida" de lo posible: [La constitución de 1925] era, en cuanto tal, la medida del modo y forma de existencia política chilena, y no existía una instancia superior a ella en el terteno propiamente constitucional. Sólo el sujeto del poder constituyente, es decir, el pueblo en su totalidad podía proclamarse superior a ella. Así, de una manera no totalmente declarada, el decreto ley 1 ha sobrepasado la constitución del 25, ha teemplazado al pueblo soberano y ha abierto de par en par en par la puerta para que la junta militar se constituya en dictadura soberana ${ }^{157}$.

Hay varias afirmaciones en esta cita sobre las que no volveré porque ya han sido suficientemente discutidas, como la idea de que al sobrepasar la constitución la puerta a la dictadura soberana ha quedado abierta de par en par: hemos visto no sólo que no quedó de par en par abierta, sino que la decisión sobre si el régimen la había abierto quedó pendiente hasta la madrugada del 6 de octubre de 1988. Pero lo que ahora nos interesa es la relación entre constitución y pueblo como sujeto del poder constituyente. La afirmación de Cristi parece suponer que hay un sujeto natural del poder constituyente, algo cuya identificación no depende de la constitución (porque es el fundamento de la validez de la constitución): este sujeto constituye "una instancia superior" a la propia constitución. El modo de actuación de este sujeto, sin embargo, es tal que su identificación no es problemática. Cristi cree que la actuación del pueblo puede ser contrastada con la actuación de la junta, de modo que podemos concluir que fue la junta y no el pueblo el que actuó en 1973. Pero lo que Cristi pierde de vista es que

155 Ackerman, "Discovering the Constitution", Ackerman, We the People: Foundations y Ackerman, We the People: Transformations.

156 Ackerman, "Discovering the Constitution", 1022.

157 Cristi, Jaime Gurmán, 83s. 
precisamente el momento en que empezamos a hablar de la expresión extrainstitucional del pueblo perdemos lo que las instituciones facilitan y tornan no-problemático que es, como hemos visto, la identificación del pueblo y las condiciones de imputación a él de una voluntad. Por consiguiente, la acción extrainstitucional (constituyente) del pueblo será siempre por interpósita persona, es decir, será siempre mediada por alguien que se arroga la representación del pueblo, tal como de hecho lo hizo la junta en 1973. El pueblo en momentos de normalidad tiene la forma que le da el derecho, mientras que en momentos excepcionales (o constitucionales, al decir de Ackerman) carece de forma ${ }^{158}$. Como carece de forma, la identificación del pueblo en esos momentos es una cuestión política, partisana: apoyar a la junta de gobierno en 1973 significaba creer que ella actuaba a nombre del pueblo mientras que estar contra ella significaba creer, con Cristi, que ella había usurpado el poder del pueblo. Pero cuando Cristi dice lo que dice (recuérdese que él mismo, como lo hemos visto, excluye de los límites de su libro lo que requiere ser "determinado políticamente, en el sentido de Schmitt"), él cree estar ocupando una posición de analista, no de partisano: él cree que está haciendo algo más que comunicarnos que él estaba entre los que se opusieron al golpe de estado. Y es ésta pretensión la que es estrictamente ininteligible.

La ceguera de Cristi a este problema es la ceguera del derecho: el derecho no puede sino trivializar el momento constituyente, porque para entenderlo debería ser capaz de entender que es posible algo así como un "momento institucional extraordinario". Para expresarlo con una terminología distinta a la que hemos utilizado hasta aquí, el derecho es un programa que controla la asignación del código binario legal/ilegal. Cualquier cosa, en principio, puede recibir cualquiera de estas eriquetas, salvo una: la aplicación del código legal/ilegal. El derecho carece aquí de la reflexividad de la política, en tanto el derecho no puede objetar jurídicamente al derecho, no puede declarar ilegal la aplicación del código legal/ilegal. Pero esto es exactamente lo que el derecho necesitaría hacer para comprender la declatación de la excepción como algo diverso a un hecho trivialmente ilícito: debería entender que es contrario a derecho declarar contrario a derecho bombardear La Moneda. El derecho, entonces, es necesariamente excluyente: la cuestión de la legalidad de la aplicación del derecho está siempre-ya respondida, está excluida.

A diferencia del derecho, como he dicho más arriba, la política tiene esta dimensión de autoreferencia: qué es un problema político es también un problema político. La comprensión de la política que subyace al argumento de Ackerman y de Cristi es problemática porque necesariamente excluye esta dimensión, asumiendo que la pregunta por la identidad de la comunidad política (o la identificación del poder constituyente, o del pueblo) no es un pregunta política sino teórica o jurídica. En Ackerman, la noción de un procedimiento "informal" de reforma constitucional es simplemente otra manera de expresar la idea de la suspensión del derecho, y por eso no tiene sentido, como veremos ahora, pretender que es posible formalizar sus condiciones de aplicación. En Cristi, las excepciones son sistemáticamente silenciadas: la constitución de 1925 fue destruida el 11 de septiembre de 1973 y reemplazada por la de 1973, que a su vez fue reformada (o suprimida y reemplazada) en 1980, la que también fue destruida en 1989 (o 1988) y reemplazada por la constitución de 1989 (o 1988). Cristi no puede apreciar la radicalidad de lo que ocurrió desde 1973 porque él no considera la posibilidad de que lo que estuvo en juego en 1973 ( $y$ en el terror que le siguió), y que no estuvo en juego en 1989 fue no sólo la pregunta política normal (¿cómo hemos de actuar?) sino también la pregunta política radical (¿quienes son parte de nosotros?).

Aceptar la reflexividad del conflicto político - el hecho de que el conflicto puede extenderse a qué cuenta como un conflicto político - impide ofrecer una caracterización no partisana que atienda a su contenido, es decir, que lo identifique por aquello sobre lo cual el conflicto versa. Aceptada la posibilidad del conflicto radical, es desde luego ingenuo pensar que el conflicto político se limita al con-

158 Y es por tanto, extraño al derecho, que "no tolera la carencia de forma" (Thering, Espiritu del Derecho Romano, 645). 
flicto sobre el bien común, o conflicto sobre la limitación del poder, o sobre la acción colectiva. Todas estas son maneras normales de entender lo político, porque suponen que la entidad cuyo bien cuenta como "común", o cuyo poder debe ser limitado, o de cuya acción se trata, no son objeto del conflicto político. Por eso lo político no puede ser caracterizado substantivamente, en términos de su contenido o los estándares a los que está sujeto. La caracterización debe mirar no al contenido del conflicto político, sino a su modo. Y eso explica la famosa caracterización de lo político ofrecida por Schmitt en su El Concepto de lo Político: La distinción política específica, aquella a la que pueden reconducirse todas las acciones y motivos políticos, es la distinción de amigo y enemigo. Lo que ésta proporciona no es desde luego una definición exhaustiva de lo político, ni una descripción de su contenido, pero si una determinación de su concepto en el sentido de un criterio ${ }^{159}$.

Esta es otra instancia del modo de caracterización utilizado por Schmitt para caracterizar la soberanía desde la excepción, que "piensa al universal al pensarse a sí misma". Aquí lo político es caracterizado desde el punto de vista de la situación extrema: el conflicto al que lo político hace alusión es conflicto comunitario (normal) y conflicto sobre la comunidad (excepcional). Lo que esto enfatiza es la naturaleza contingente de la comunidad política: la comunidad se define a sí misma. El conflicto político tiene en sí la potencialidad de tornarse reflexivo.

Como fue mencionado más arriba, Ackerman considera que la fuente del nazismo de Schmitt, la premisa de la que éste se deriva, es su preferencia por la aclamación como forma privilegiada de la expresión del pueblo. Intentando impedir que "nazis como Schmitt desacrediten enteramente la idea" de que los ciudadanos pueden expresarse por formas no institucionales, Ackerman propone "un número de criterios para identificar un acto apropiado de voluntad constitucional"160. Esos criterios incluyen, primero, el tiempo: no debería ser suficiente obtener apoyo [...] para un principio constitucional en un único momento [... . ] Debería fijarse un período de tiempo considerable - medido en años, no en meses- en el cual una iniciativa constitucional pueda ser debatida en múltiples foros decisorios antes de determinar su destino ${ }^{161}$.

Pero aquí debe recordarse que el equivalente institucional de estos criterios (el primero mencionado y los demás que no necesitamos mencionar, pero que incluyen una exigencia especial de profundidad, amplitud y contundencia del apoyo popular para la iniciativa constitucional en cuestión) es el artículo $\mathrm{V}$ de la constitución (que regula el procedimiento de reforma). ¿Por qué eso no es suficiente? Porque Ackerman está hablando precisamente de los momentos constitucionales, es decir, como vimos, de los momentos en que el pueblo se manifiesta a través de "formas institucionales extraordinarias". Y estos requisitos, estas exigencias, esta "fijación de plazos" de años y no meses, etc, ¿cuál es su estatus? Si lo que Ackerman pretende es sólo sugerencias para sobre cómo debería diseñarse un sistema superior de creación de derecho (higher lawmaking system) que pueda correctamente distinguir entre las raras ocasiones en las que una mayoría movilizada de ciudadanos americanos se forma un juicio considerado en un asunto de principios fundamental es y las incontables decisiones de politica normal ${ }^{162}$ entonces el problema ya está resuelto: es el procedimiento institucional de reforma constitucional, y lo que Ackerman dice puede ser entendido como sugerencias de modificación de ese sistema. Pero eso no responde la pregunta por las formas institucionales extraordinarias. Tratándose de éstas, no se ve por qué el pueblo no puede también decidir cómo quiere expresarse. Las condiciones que Ackerman exige para la existencia de un momento de política constitucional invitan naturalmente a la pregunta: ¿qué hemos de concluit si esos requisitos no se dan, pero un movimiento político se muestra capaz de imponer su concepción de la comunidad? ¿ $\mathrm{O}$ si estos requisitos concurren, pero

159 Schmitt, Concepto de lo Polition, 55.

160 Ackeman, La Politica del Diálogo Liberal, 151.

161 ibid.

162 Ackerman, We the People: Foundations, 55. 
la decisión adoptada es una que niega mi comprensión de los fundamentos de nuestra asociación politica?

Ackerman dice algo respecto de la segunda cuestión. Él imagina que, después de la debida deliberación, se dicta la siguiente enmienda XXVII de la constitución norteamericana:

El cristianismo es la religión del pueblo americano, y el culto público de otros dioses está probibido.

Luego, comentando este escenario, sostiene que no tendría dudas sobre mi responsabilidad judicial, si fuera tan infortunado como para ser miembro de la Corte Suprema. A pesar de que yo mantendría mi convicción de que esta enmienda cristiana está terriblemente equivocada, yo la defendería como una parte fundamental de la constitución americana ${ }^{163}$.

Aquí Ackerman está imaginando la situación en la que se encontraría un juez de la Corte Suprema después de la modificación regular de la constitución norteamericana, es decir, mediante el artículo V. Todo el proyecto de Ackerman, sin embargo, supone que esta enmienda XXVII puede ser adoptada no sólo mediante este procedimiento, sino también mediante "formas institucionales extraordinarias". En el primer caso, Ackerman puede hablar de su responsabilidad judicial de defender la enmienda XXVII como una parte fundamental de la constitución americana porque ella ha sido producida mediante los procedimientos que, desde el punto de vista del juez, permiten imputar al pueblo norteamericano una voluntad. Pero si aceptamos la idea de formas institucionales extraordinarias, es decir, de reformas constitucionales que se realizan a través de formas distintas a las del artículo V, ¿por qué habría un juez de aceptar la imputación al pueblo americano de una voluntad que, de acuerdo a la visión de ese juez, niega aquello que es más característicamente constitutivo de la idea política de pueblo norteamericano? ¿Por qué deberíamos aceptar la tesis de Ackerman de que es responsabilidad del juez aceptar que es el pueblo norteamericano el que ha hablado? Radicalizando este punto, podemos concluir: si se trata de formas extraordinarias, no formales, de manifestación del pueblo, no hay otro criterio de imputabilidad que la coherencia sustantiva de la voluntad expresada y la comprensión de la comunidad política del agente de que se trata. No hay aquí espacio para la perspectiva del juez, porque no hay espacio para sostener lo que es característico de la posición judicial: que una decisión es institucionalmente válida a pesat de que es contraria a las creencias del juez. La cuestión de la identificación del pueblo como agente político y de la imputabilidad a él de una voluntad son excluidas radicalmente por el derecho: están always-already respondidas. Es en este sentido que el derecho es necesariamente excluyente y no reflexivo.

¿Y quién dice que el derecho es excluyente y no reflexivo? ¿Por qué no puede, en otras palabras, aplicar el código legal/ilegal al derecho mismo? No puede hacerlo y seguit siendo derecho. Y esto no es una cuestión sobre el significado de la palabra "derecho", sino sobre el sentido del derecho. Sólo porque el derecho no puede aplicar él código legal/ilegal al derecho mismo es que la aplicación del código legal/ilegal no es políticamente problemática, al menos no lo es al interior del derecho. Precisamente porque el conflicto político es reflexivo y no admite exclusiones formales, como las admite el derecho, es que existe el derecho para configurar un ámbito de interacción libre de la contingencia de la política. Esperar que el derecho aplique el código legal/ilegal al derecho mismo es esperar que se haga reflexivo, es decir, que deje de ser derecho y se transforme en política. Esto es lo que algunos denominamos "vulgarización" del derecho. La vulgatización del derecho lo disuelve.

\section{Referencias}

1. Ackerman, B: La Politica del Diálogo Liberal (Barcelona: Gedisa, 1999; traducido por G Alonso).

163 ibid, 14. 
- "The Storr Lectures: Discovering the Constitution", en 93 Yale Law Journal (1984).

-We the People: Foundations (Cambridge, MA: Harvard University Press, 1991).

-We the People: Transformations (Cambridge, MA: Harvard University Press, 1998).

2. Agamben, G: Homo Sacer (Stanford: Stanford University Press, 1998; edn orig 1995).

3. Arendt, H: The Human Condition (Chicago, IL: University of Chicago Press, 1958).

-On Vialence (San Diego, CA: Harcourt Brace and Company, 1969).

4. Atria, F: On Law and Legal Reasoning (Oxford: Hart Publishers, 2002).

-"El derecho y la contingencia de lo político", en 26 DOXA (2004), pp 319-345.

“¿Existen derechos sociales?” en 4 Discusiones (2004), pp 15-59.

- "La itonía del positivismo jurídico", en 28 Doxa (2006).

- "Reconciliation and reconstitution", en Veitch, S (ed): Law, Time and Reconciliation (Aldershot: Ashagate, de próxima aparición).

5. Bankowski, Z: Living Lawfully (Dordrecht: Kluwer, 2001).

6. Barros, R: La Junta Militar. Pinochet y la constitución de 1980 (Santiago: Sudamericana, 2005).

7. Böckenförde, W: "El poder constituyente del pueblo. Un concepto límite del derecho constitucional", en Estudios sobre el Estado de Derecho y la Democracia (Madrid: Trotta, 2000), pp 159-180.

8. Bodino, J: Los Seis Libros de la República (Madrid: Centro de Estudios Constitucionales, 1992; edn orig 1575).

9. Boff, L: Jesucristo el Liberador. Ensayo de cristología crítica para nuestro tiempo (Santander: Sal Terrae, 1980).

10. Carrió, G: "Sobre los límites del lenguaje normativo", en Notas sobre Derecho y Lenguaje (Buenos Aires: Abeledo Perrot, 1994), pp 237-282.

11. Cavallo, A, M Salazar y O Sepúlveda: La Historia Oculta del Régimen Militar (Santiago: Grijalbo Mondadori, 1997; edn orig 1990).

12. Cohen, G A: If You're Egalitarian, How Come You Are so Rich? (Cambridge, MA: Harvatd University Press, 2000).

13. Cristi, R: Carl Scbmitt and Autoritharian Liberalism (Cardiff: University of Wales Press, 1998).

-El Pensamiento Político de Jaime Guzmán (Santiago: LOM, 2000).

14. Christodoulidis, E: Law and Reflexive Politics (Dordrecht: Kluwer, 1998). 
15. Dworkin, R: Law's Empire (London: Fontana, 1986; traducido por C Ferrari).

16. Dyzenhaus, D: Legality and Legitimacy (Oxford: Clarendon Press, 1997).

17. Eagleton, T: After Theory (London: Penguin, 2004).

18. Gazmuri, C: Eduardo Frei Montalva y su Época (Santiago: Aguilar, 2000).

19. Guzmán, A: Derecho Privado Romano (Santiago: Editorial Jurídica de Chile, 1996).

20. Hart, H. L A: El Concepto de Derecho (Buenos Aires: Abeledo-Perrot, 1963; traducido por G Carrió).

-"Self-teferring laws", en Essays in Jurisprudence and Pbilosopby (Oxford: Clarendon Pres, 1983).

21. Hobbes, T: Leviathan (Oxford: Oxford University Press, 1965; edn orig 1651).

22. Hohfeld, W N: Conceptos Jurídicos Fundamentales (México: Fontamara, 2001; edn orig 1923).

23. Holmes, S: "The liberal idea", en Passions 2 Constraint (Chicago: University of Chicago Press, 1995), pp 13-41.

24. Thering, R: El Espiritu del Derecho Romano (Granada: Comares, 1852-1865; edn orig 1998).

25. Jolowicz: Historical Introduction to the Study of Roman Law (Cambridge: Cambridge University Press, 1967; edn orig 1932).

26. Kant, I: La Contienda entre las Facultades de Filosofia y Teologia (Madrid: Trotta, 1999; traducido por R Rodríguez).

27. Kelsen, H: Teoría Pura del Derecbo (1960) (México: Porrúa, 1991; edn orig 1960; traducido por R J Vernengo).

28. Kierkegaard, S: Fear and Trembling (Princeton, NJ: Princeton University Press, 1983; edn orig 1843).

-Repetition (Princeton: Princeton University Press, 1983; edn orig 1843).

29. Klarman, M: "Constitutional fact/constitutional fiction: a critique of Bruce Ackerman's theory of constitutional moments", en Stanford Law Review (1992), pp 759-799.

30. Macintyre, A: After Virtwe. A Study in Moral Theory (London: Duckworth, 1985).

31. Marx, K y F Engels: La Sagrada Familia, o Crítica de la crítica crítica contra Bruno Bauer y consortes (Madrid: Akal, 1977; edn orig 1845).

32. Mommsen, T: Compendio de Derecho Público Romano (Buenos Aires: Editorial Impulso, 1942). 
33. Montesquieu: Del Espiritu de las Leyes (Buenos Aires: Heliasta, 1984; edn orig 1748; traducido por N Estevanez).

34. Morton, A (ed): Beyond Fear: Vision, Hope and Generosity (Edinburgh: Saint Andrew Press, 1998).

35. Mouffe, C: El Retorno de lo Politico (Madrid: Paidos, 1999).

36. Moulian, T: La Forja de Ilusiones. El sistema de partidos, 1932-1973 (Santiago: Arcis/FLACSO, 1993).

37. Rawls, J: Political Liberalism (New York, NY: Columbia University Press, 1993; traducido por S R Madero).

38. Rivera, E: "Violencia y derecho", en Violencia y derecho (Buenos Aires: Editores del Puerto, 2004).

39. Rose, G: The Broken Middle (Oxford: Blackwell, 1992).

40. Ross, A: Sobre el Derecbo y la Justicia (Buenos Aires: Eudeba, 1994; edn orig 1953).

41. Rubenfeld, J: Freedom and Time (New Haven, CT: Yale University Press, 2001).

42. Schmitt, C: El Concepto de lo Politico (Madrid: Alianza, 1998; edn orig 1932; traducido por R Agapito).

-La Dictadura (Madrid: Alianza, 1999; edn orig 1931).

-Romanticismo Politico (Buenos Aires: Universidad Nacional de Quilmes, 2001; edn orig 1919).

-State, Movement, People (Corvallis: Plutarch Press, 2001; edn orig 1933).

-Teología Politica (Buenos Aires: Struhart y Cía, 1998; edn orig 1922).

- Teoría de la Constitución (Madrid: Alianza, 1992; edn orig 1928; traducido por F Ayala).

43. Schulz, F: Derecho Romano Clásico (Bacelona: BOSCH, 1960; traducido por Santa Cruz, I).

44. Segundo, J L: La Historia Perdida y Recuperada de Jesús de Nazaret (Santander: Sal Terrae, 1991).

45. Sieyès, E-I: ¿Qué es el Estado Llano? (Madrid: Centro de Estudios Constitucionales, 1988; edn orig 1789).

46. Waldron, J: Law and Disagreement (Oxford: Clarendon Press, 1999).

47. Watson, A: The Evolution of Law (Oxford: Basil Blackwell, 1985).

48. Weil, S: La Gravedad y la Gracia (Madrid: Trotta, 1998; edn orig 1947). 
-Pensamientos Desordenados (Madrid: Trotta, 1995; edn orig 1949; traducido por M Tabuyo y A López).

49. Wittgenstein, L: Pbilosophical Investigations (Oxford: Blackwell, 1958; traducido por G E M Anscombe).

50. Wood, G: El Plebiscito Constitucional de 1925 (Santiago: Editorial Jutídica de Chile, 1953).

51. Young, P: "The importance of utopias in criminological thinking", en 32 British Journal of Criminology (1992), pp 423-437. 